\title{
Autism-Associated Mutations in ProSAP2/Shank3 Impair Synaptic Transmission and Neurexin-Neuroligin-Mediated Transsynaptic Signaling
}

\author{
Magali H. Arons, ${ }^{1 \star}$ Charlotte J. Thynne, ${ }^{2 \star}$ Andreas M. Grabrucker, ${ }^{1,3}$ Dong Li, ${ }^{2}$ Michael Schoen, ${ }^{3}$ Juliette E. Cheyne, ${ }^{2}$ \\ Tobias M. Boeckers, ${ }^{3}$ Johanna M. Montgomery, ${ }^{2}$ and Craig C. Garner ${ }^{1}$ \\ ${ }^{1}$ Department of Psychiatry and Behavioral Sciences, Stanford University, Stanford, California 94304, ${ }^{2}$ Department of Physiology, University of Auckland, \\ Auckland 1142, New Zealand, and ${ }^{3}$ Institute of Anatomy and Cell Biology and ${ }^{4}$ Neurology Department, Ulm University, D-89081 Ulm, Germany
}

Mutations in several postsynaptic proteins have recently been implicated in the molecular pathogenesis of autism and autism spectrum disorders (ASDs), including Neuroligins, Neurexins, and members of the ProSAP/Shank family, thereby suggesting that these genetic forms of autism may share common synaptic mechanisms. Initial studies of ASD-associated mutations in ProSAP2/Shank3 support a role for this protein in glutamate receptor function and spine morphology, but these synaptic phenotypes are not universally penetrant, indicating that other core facets of ProSAP2/Shank3 function must underlie synaptic deficits in patients with ASDs. In the present study, we have examined whether the ability of ProSAP2/Shank3 to interact with the cytoplasmic tail of Neuroligins functions to coordinate pre/postsynaptic signaling through the Neurexin-Neuroligin signaling complex in hippocampal neurons of Rattus norvegicus. Indeed, we find that synaptic levels of ProSAP2/Shank3 regulate AMPA and NMDA receptor-mediated synaptic transmission and induce widespread changes in the levels of presynaptic and postsynaptic proteins via Neurexin-Neuroligin transsynaptic signaling. ASD-associated mutations in ProSAP2/Shank3 disrupt not only postsynaptic AMPA and NMDA receptor signaling but also interfere with the ability of ProSAP2/Shank3 to signal across the synapse to alter presynaptic structure and function. These data indicate that ASD-associated mutations in a subset of synaptic proteins may target core cellular pathways that coordinate the functional matching and maturation of excitatory synapses in the CNS.

\section{Introduction}

Autism spectrum disorders (ASDs) are a set of neurodevelopmental disorders characterized by impairments in communication and social behavior and by repetitive or stereotyped behaviors (Bailey et al., 1996; Miles, 2011). Although these characteristics are common across individuals with ASDs, a great deal of heterogeneity exists, suggesting a complex etiology. Emerging data point to a strong genetic component, with mutations in multiple genes linked to ASDs (Polleux and Lauder, 2004; Kumar and Christian, 2009). Many of these encode proteins found at excitatory glutamatergic synapses, including ProSAP2/Shank3, Neuroligins (NL3 and NL4), Neurexin1 (Nrx1), Cadherins, frag-

Received May 4, 2012; revised Aug. 10, 2012; accepted Aug. 25, 2012.

Author contributions: M.H.A., C.J.T., A.M.G., J.M.M., and C.C.G. designed research; M.H.A., C.J.T., D.L., and J.E.C. performed research; A.M.G., M.S., and T.M.B. contributed unpublished reagents/analytic tools; M.H.A., C.J.T., D.L., and J.M.M. analyzed data; M.H.A., C.J.T., J.M.M., and C.C.G. wrote the paper.

This work was supported by National Institute of Neurological Disorders and Stroke National Research Service Award Fellowship Grant 5F31NS066786-025 (M.H.A.), a fellowship from the German Research Foundation (A.M.G.), National Institutes of Health Grants P01 NS053862 and R21 MH091471 (C.C.G.), United States Israel Binational Science Foundation Grant 2007425 (C.C.G.), and the Neurological Foundation of New Zealand and the Auckland Medical Research Foundation (C.J.T., D.L. and J.M.M.).

The authors declare no competing financial interests.

*M.H.A. and C.J.T. contributed equally to this work.

Correspondence should be addressed to Craig C. Garner, Stanford University School of Medicine, Department of Psychiatry and Behavioral Sciences, 1201 Welch Road, Stanford, CA 94304-5485; E-mail: cgarner@stanford.edu.

DOI:10.1523/JNEUROSCI.2215-12.2012

Copyright $\odot 2012$ the authors $\quad 0270-6474 / 12 / 3214966-13 \$ 15.00 / 0$ ile X mental retardation protein 1 (FMRP1), and UBE3 among others (Kumar and Christian, 2009), suggesting that phenotypic expression of ASDs may, at least in part, be attributed to excitatory synapse dysfunction. A fundamental question raised by these studies is how mutations in so many different genes can elicit a shared set of behavioral phenotypes. One attractive but untested mechanism is that they shift the functionality of neuronal circuits by subtly altering some common facet of synapse formation, stability, maturation, or plasticity.

Recent studies offer insights into potential synaptic mechanisms underlying ASDs. For example, synaptic levels of glutamate receptors are regulated by FMRP1 and UBE3 (Dölen et al., 2010). ASD-associated mutations in Cadherins (Cadh8Cadh10), Neurexins (Nrx1-Nrx3), and Neuroligins (NL1, NL3, NL4X, and NL4Y) imply that the strength of synaptic adhesion may also be compromised (Kumar and Christian, 2009), a concept supported by studies showing that Nrx/NL complexes signal bidirectionally to promote pre/postsynaptic differentiation (Scheiffele et al., 2000; Graf et al., 2004). It remains unclear how Nrx/NL complexes signal across the synapse, although a variety of binding partners have been identified, including PSD-95 (Irie et al., 1997; Futai et al., 2007) and the ProSAP/Shank protein family (Boeckers et al., 2002; Meyer et al., 2004).

ASD-associated mutations have been found in ProSAP2/ Shank3 and ProSAP1/Shank2 (Durand et al., 2007; Moessner et al., 2007; Gauthier et al., 2009; Berkel et al., 2010; Grabrucker et 
al., 2011b) and more recently in ProSAP3/Shank1 (Kumar and Christian, 2009; Sato et al., 2012). Intriguingly, patients with Phelan McDermid syndrome, a syndrome with autism-like features, is associated with the loss of one copy of ProSAP2/Shank3 (Wilson et al., 2003; Phelan, 2008), whereas three copies of ProSAP2/Shank3 has been linked to Asperger's syndrome (Moessner et al., 2007). Structure-function studies have shown that ProSAP/ Shank family members interact with numerous postsynaptic density proteins, including Homer, ionotropic and metabotropic glutamate receptors, and components of the actin cytoskeleton (Kreienkamp, 2008). Both ProSAP2/Shank3 and ProSAP3/Shank1 regulate spine morphology and AMPA/NMDA receptor signaling. However, isoform-specific functions that can account for the prominent role of ProSAP2/Shank3 in ASD-related synaptic dysfunction have not been identified.

In the present study, we have examined the effects of modulating ProSAP2/Shank3 levels on excitatory synapses. Our data show that ProSAP2/Shank3 levels trigger changes in pre/postsynaptic function that requires transsynaptic signaling through Nrx/NL complexes. Moreover, ProSAP2/Shank3 carrying ASDassociated mutations equally impair coordinated changes in pre/ postsynaptic function. These data indicate that the maintenance of synaptic maturation mediated by Nrx/NL transsynaptic signaling may be a core cellular function targeted by ASD-associated mutations in ProSAP2/Shank3.

\section{Materials and Methods}

Neuronal cultures. The preparation of hippocampal cultures from both male and female Wistar rat embryos was performed essentially as described by Goslin et al. (1988). Cell culture experiments of hippocampal primary neurons from rat embryos (embryonic day 18) were performed as described previously (Leal-Ortiz et al., 2008). All animal experiments were performed in compliance with the guidelines for the welfare of experimental animals issued by the National Institutes of Health. All of the experiments were conducted in strict compliance with Administrative Panel on Laboratory Animal Care-approved animal protocols from Stanford University and the University of Auckland.

Expression constructs and transfection. The pEGFP (C1-3) vector system (Clontech) was used for the ProSAP2/Shank3 expression constructs. Full-length ProSAP2/Shank3 rat cDNAs were cloned into these vectors. ProSAP2/Shank3 target sequences were used as described previously (Roussignol et al., 2005; Grabrucker et al., 2011a), and short-hairpin RNA (shRNA) oligonucleotides were synthesized and cloned into a pSUPER and pFUGW H1 via a pZOff vector (Leal-Ortiz et al., 2008). The four ProSAP2/Shank3 autism mutations (R87C, R375C, Q396R, and InsG) were cloned into the full-length rat ProSAP2/Shank3 C1-3 pEGFP Clontech vector using site-directed mutagenesis based on the human mutations (R12C, R300C, Q321R, and InsG) and have been described previously (Durand et al., 2012).

Hippocampal cells were transfected at $9 \mathrm{~d}$ in vitro (DIV9) using Lipofectamine 2000 Reagent (Invitrogen). For each coverslip in a six-well plate, $2.5 \mu \mathrm{l}$ of Lipofectamine 2000 with $50 \mu \mathrm{l}$ of OptiMEM medium were incubated for $5 \mathrm{~min}$ at room temperature before mixing with $50 \mu \mathrm{l}$ of OptiMEM medium and $5 \mu \mathrm{g}$ of DNA per well and incubated for $30 \mathrm{~min}$ before adding the mixture to the cells. After $1-2 \mathrm{~h}$ of transfection incubation in Neurobasal medium containing $10 \mu \mathrm{M}$ CNQX and $50 \mu \mathrm{M}$ APV, cells were returned to their original plates with fresh Neurobasal medium containing B27 and L-glutamine. For electrophysiological studies, neurons were transfected at DIV9 using calcium phosphate precipitation (Waites et al., 2009). Briefly, for each $25 \mathrm{~mm}$ culture well, $4 \mu \mathrm{g}$ of DNA and $7.5 \mu \mathrm{l}$ of $2 \mathrm{M} \mathrm{CaCl}_{2}$ in $60 \mu \mathrm{l}$ volume was added dropwise to $60 \mu \mathrm{l}$ of $2 \times$ HBS (in mm: $274 \mathrm{NaCl}, 10 \mathrm{KCl}, 1.4 \mathrm{Na}_{2} \mathrm{HPO}_{4}, 15$ glucose, and 42 HEPES, pH 7.1) and incubated for $20 \mathrm{~min}$. The DNA mixture was then added to cultured neurons in $1 \mathrm{ml}$ of conditioned medium plus $10 \mu \mathrm{M}$ CNQX and $50 \mu \mathrm{M} \mathrm{APV}$ and incubated for $20-45 \mathrm{~min}$ at $37^{\circ} \mathrm{C}$ before washing and transferring back into culture dishes.
Antibodies, Western blots, and immunostaining. Primary antibodies were purchased from Synaptic Systems (Homer1, Neuroligin1, Neuroligin3, Synapsin, Munc13, and VAMP2), Santa Cruz Biotechnology (Synaptophysin), Sigma (PSD-95), and NeuroMab (VGLUT1). Polyclonal antibodies against Piccolo (Zhai et al., 2000) and ProSAP2/Shank3 (Zhai et al., 2000; Grabrucker et al., 2011a) were used as described previously. Immunoblots of cellular lysates were prepared from lentivirally infected hippocampal neurons as described previously (Leal-Ortiz et al., 2008). In brief, neurons were infected with a lentiviral vectors expressing an shRNA against ProSAP2 (sh-ProSAP2) and/or EGFP at DIV0. Lysates from these neurons or those left uninfected were collected at DIV14 and used for Western blot analysis. Protein levels were standardized using tubulin.

Dissociated hippocampal neurons were fixed at DIV16 in 4\% paraformaldehyde with sucrose for 3-4 min and then transferred to ice-cold methanol for an additional $15 \mathrm{~min}$ of fixation. Cells were then washed, permeabilized with $0.25 \%$ Triton X-100 in $1 \times$ PBS for 5 min, washed in PBS, incubated in blocking solution (2\% bovine serum albumin, $2 \%$ glycine, and $0.2 \%$ gelatin in $50 \mathrm{mM} \mathrm{NH}_{4} \mathrm{Cl}$ ) for $30 \mathrm{~min}$ at room temperature, and incubated with primary antibodies in blocking solution for $1 \mathrm{~h}$ at room temperature. Afterward, cells were rinsed three to four times in PBS, incubated for $1 \mathrm{~h}$ at room temperature with secondary antibodies in blocking solution, rinsed again three to four times in PBS, followed by a final rinse in deionized water, dried, and mounted in Vectashield mounting solution (Vector Laboratories).

FM4-64 loading. FM loading was performed using FM4-64 from Invitrogen. Coverslips of neuron cultures were live mounted in a perfusion system optimized for live imaging experiments. After baseline images were acquired, the FM4-64 dye was loaded by perfusing $3 \mathrm{ml}$ of highpotassium Tyrode's solution with $1 \mu$ l of FM4-64 to depolarize the cells, followed by $3 \mathrm{ml}$ of normal Tyrode's solution also with $1 \mu \mathrm{l}$ of FM4-64 facilitating the complete cycle of vesicle recycling. Finally, $10 \mathrm{ml}$ of Tyrode's solution was used to wash away any residual FM4-64 dye that had not been taken up into cells.

Transsynaptic blockers: $N$-cadherin antibody, integrin peptide, and soluble $\beta$-neurexin. Transsynaptic blocking experiments were preformed as described previously (Regalado et al., 2006) with only slight modifications. N-cadherin antibodies (clone GC-4) and the GRGDSP (Gly-ArgGly-Asp-Ser-Pro) integrin blocking peptide were purchased from Sigma-Aldrich. The N-cadherin antibody was used at 1:100, and $1 \mathrm{~mm}$ GRGDSP peptide was used to treat cells after ProSAP2/Shank3 transfection on DIV12 and replenished on DIV13 and DIV14; cells were fixed at the end of the day on DIV14.

Purified protein and DNA for soluble neurexin- $1 \beta(+S 4)-F c$ and neurexin- $1 \beta-\Delta$ LNS-Fc were generously provided by Ann Marie Craig (University of British Columbia, Vancouver, Canada) with permission from Peter Scheiffele (Biocentrum, Basel, Switzerland). Cell treatment protocol was followed, as recommended and described previously (Siddiqui et al., 2010), applying $50 \mu \mathrm{g} / \mathrm{ml}$ each day for $2 \mathrm{~d}$. EGFP-ProSAP2 transfection was performed on DIV12, cells were treated with soluble protein on DIV12-DIV14, and then cells were fixed at DIV14.

Additional protein was produced as described previously (Siddiqui et al., 2010). In brief, HEK293T cells were grown in T300 flasks containing DMEM-Ham's F-12 with 10\% FBS and then transferred to 5\% FBS DMEM and transfected using $96 \mu \mathrm{l}$ of Calfectin and $32 \mu \mathrm{g}$ of DNA. The following day, cells were transferred to serum-free medium, and protein production continued for $40 \mathrm{~h}$. At this time, cells were collected, treated with PMSF, and concentrated using a Centricon-70 unit (Millipore). The sample was treated with COMPLETE mini-protease inhibitor tablet (Roche) and stored until purification. The Immunopure Protein-A IgG kit (Pierce Thermo Fisher Scientific) was used for protein purification.

Synaptic measurements, analysis, and statistics. Fluorescent images were taken on a Carl Zeiss Axiovert 200M microscope equipped with a PerkinElmer Life and Analytical Sciences spinning disc confocal head, a Hamamatsu 512B camera, and MetaMorph image acquisition software. Puncta-by-puncta analysis was performed using Openview software (Noam Ziv, Haifa, Israel) as described previously (Friedman et al., 2000; Leal-Ortiz et al., 2008). In brief, Homer1 or PSD-95 immunopositive fluorescent puncta were individually boxed and selected based on the 
following criteria: selected puncta must be above background intensity values in both the immunostained channels, the puncta must be discrete and non-overlapping, and there must be good spatial separation of EGFP-positive versus EGFP-negative puncta. The software measures puncta intensity values in each of the channels, and subsequent data analysis reveals trends in the data. Statistical analysis was performed using Prism software (GraphPad Software), data were tested for significance using two-tailed, Student's $t$ test and ANOVA, and $p$ values $<0.05$ were stated as significant $\left({ }^{*} p<0.05,{ }^{* *} p<0.01,{ }^{* *} p<0.001,{ }^{* * * *} p<\right.$ 0.0001).

Paired whole-cell recordings. Paired whole-cell patch-clamp recordings to measure synaptic transmission between pyramidal neurons in vitro were performed as described previously (Waites et al., 2009; Li et al., 2011). Briefly, hippocampal neurons from male and female P0 Wistar rat pups were plated on $12 \mathrm{~mm}$ round glass coverslips, transferred to a recording chamber mounted on an Olympus BX-51 microscope, and perfused at room temperature with artificial CSF (ACSF) (in mM): 119 $\mathrm{NaCl}, 2.5 \mathrm{KCl}, 1.3 \mathrm{MgSO}_{4}, 2.5 \mathrm{CaCl}_{2}, 1 \mathrm{Na}_{2} \mathrm{HPO}_{4}, 26.2 \mathrm{NaHCO}_{3}$, and 11 glucose). When recording miniature EPSCs (mEPSCs), the ACSF also contained $1 \mu \mathrm{M}$ tetrodotoxin and $100 \mu \mathrm{M}$ picrotoxin (Waites et al., 2009). Neurons were visualized by infrared differential interference contrast microscopy, and postsynaptic neurons transfected with EGFP-tagged ProSAP2/Shank3 were identified by fluorescence imaging. Presynaptic neurons were held in current clamp and induced to fire action potentials by brief injection of depolarizing current (typically $300-450 \mathrm{pA}$ for 20 $\mathrm{ms}$ ). To measure AMPA receptor (AMPAR)-mediated synaptic currents, postsynaptic neurons were held in voltage-clamp mode at $-65 \mathrm{mV}$ (Multiclamp; Molecular Devices). NMDAR-mediated currents were measured by bath application of the AMPAR antagonist CNQX $(10 \mu \mathrm{M})$ while holding the postsynaptic neuron at $+40 \mathrm{mV}$. Series resistance $\left(R_{\mathrm{s}}\right)$ was monitored throughout the duration of the recording, and data were excluded if $R_{\mathrm{s}}$ increased $>20 \%$. Internal solution consisted of the following (in $\mathrm{mm}$ ): 120 potassium (presynaptic) or cesium (postsynaptic) gluconate, 40 HEPES, $5 \mathrm{MgCl}_{2}, 0.3 \mathrm{NaGTP}, 2 \mathrm{NaATP}$, and 5 QX314 (postsynaptic cell only), $\mathrm{pH} 7.2$ with $\mathrm{KOH}$. Monosynaptic excitatory connections were evident as an inward current into the postsynaptic neuron occurring within $5 \mathrm{~ms}$ of the peak of the presynaptic action potential. Failures of synaptic transmission were defined as trials indistinguishable from baseline and were evident by a lack of postsynaptic current immediately after the presynaptic action potential. Baseline EPSCs in response to presynaptic action potential firing were collected at $0.1 \mathrm{~Hz}$. Paired-pulse stimulation was performed in paired whole-cell recordings between two pyramidal neurons. Two presynaptic action potentials, $50 \mathrm{~ms}$ apart, were delivered by current injection to the presynaptic cell, and the amplitudes of the two postsynaptic AMPAR-mediated EPSCs were recorded. A minimum of 25 independent stimulations were conducted for each paired whole-cell recording, and the average pairedpulse ratio was calculated. All drugs were bath applied without altering the perfusion rate of ACSF. To measure potential changes in release probability, MK-801 $(40 \mu \mathrm{M})$ was bath applied in the presence of $10 \mu \mathrm{M}$ glycine to augment NMDA currents, and the amplitude of subsequent NMDAR-mediated currents were normalized to the average NMDARmediated currents measured before application of MK-801. Online data acquisition and offline analysis of AMPAR and NMDAR-mediated EPSCs were performed with pClamp (Clampex version 9.2). Statistical significance of changes in AMPAR and NMDAR EPSC amplitudes were tested using two-tailed Student's $t$ test, ANOVA, or the Mann-Whitney $U$ test, with the level of significance set at ${ }^{*} p<0.05$. mEPSCs were detected and analyzed with MiniAnalysis (version 6.0.3; Synaptosoft) as described previously (Waites et al., 2009).

\section{Results}

\section{Postsynaptic ProSAP2/Shank3 elicits transsynaptic changes} in presynaptic protein levels and function

In addition to interacting with structural elements of the PSD involved in F-actin assembly, ProSAP2/Shank3 also interacts with ionotropic and metabotropic glutamate receptors, as well as $\mathrm{IP}_{3} \mathrm{Rs}$ (Kreienkamp, 2008). ProSAP2/Shank 3 has also been found to directly interact with the cytoplasmic tails of Neuroligins (Meyer et al., 2004) (M.S. and T.M.B., unpublished observations), suggesting that, in addition to changing the dendritic spine morphology and glutamate receptor function, ProSAP2/ Shank 3 levels may influence facets of presynaptic function, perhaps through the activation of transsynaptic Neurexin/Neuroligin complexes. To test this hypothesis, we initially examined whether the overexpression of ProSAP2/Shank3, as occurs in Asperger's syndrome, affected levels of several presynaptic proteins, including the synaptic vesicle (SV) proteins VGLUT1, Synaptophysin, Synapsin, and VAMP2, as well as the active zone proteins Piccolo and Munc13 (Garner and Shen, 2007; Jin and Garner, 2008). Overexpression was achieved by transfecting hippocampal neurons with an EGFP-tagged $\alpha$-isoform of ProSAP2/Shank3 (EGFP$\alpha$ ProSAP2), which includes the N-terminal Ankyrin repeats (Wang et al., 2011). As controls, we also assessed changes in the postsynaptic proteins PSD-95 (Cho et al., 1992; Kistner et al., 1993), Homer1 (Brakeman et al., 1997), and NL1 and NL3 (Fig. 1). A systematic puncta-by-puncta analysis revealed coordinated increases in a variety of presynaptic proteins at synapses overexpressing postsynaptic EGFP- $\alpha$ ProSAP2 compared with synapses from untransfected neurons in the same field of view. Specifically, the SV markers VGLUT1 and Synaptophysin were increased by 55 and $50 \%$, respectively, Munc13, which regulates SV priming and exocytosis, was increased by $38 \%$, and Synapsin, which is involved with regulation of SV pool size, was increased by $50 \%$. Moreover, the SNARE protein VAMP2 had a $38 \%$ increase, and the presynaptic scaffolding protein Piccolo had a 50\% increase. There was also a concomitant $43 \%$ increase in the puncta intensity of the ProSAP2/Shank3 binding protein Homer1, consistent with previous findings (Xiao et al., 2000; Sala et al., 2001), as well as a 41,31 , and $32 \%$ increase in PSD-95, NL1, and NL3, respectively (Fig. $1 B$ ). Importantly, a more detailed analysis of cumulative histograms for VGLUT1 and Homer1 revealed a coordinated increase in their levels that scaled with postsynaptic levels of EGFP- $\alpha$ ProSAP2 (Fig. 1C,D).

As an additional measure of presynaptic changes occurring as a result of postsynaptic EGFP- $\alpha$ ProSAP2 overexpression, we examined whether the size of the total recycling pool (TRP) of SVs, as measured by the uptake of the styryl dye FM4-64 after a 60-s 90 mM $\mathrm{KCl}$ stimulation (Fig. 2), was altered. Compared with boutons situated on nontransfected cells, the TRP was increased by $40 \%$ at boutons juxtaposed with postsynaptic EGFP- $\alpha$ ProSAP2 puncta (Fig. $2 A, D$ ). Moreover, the expression of EGFP- $\alpha$ ProSAP2 led to a small but not significant increase in the number of synapses per unit length of dendrite compared with control EGFP-alone transfected cells (10 synapses $/ 10 \mu \mathrm{m}$ vs 8 synapses $/ 10 \mu \mathrm{m}$ ) (Fig. $1 E$ ). Together, these data imply that ProSAP2/Shank3 uses its multidomain structure to coordinately regulate facets of presynaptic and postsynaptic function that promote increases in the size, function, and number of excitatory synapses.

We next examined whether the downregulation of ProSAP2/ Shank3 using RNA interference affected the abundance of pre/ postsynaptic proteins, the TRP of SVs, and/or synapse number. The knockdown efficacy using shRNAs against ProSAP2/Shank3 (Roussignol et al., 2005; Grabrucker et al., 2011a) was examined by Western blot analysis of cellular lysates from hippocampal neurons infected with lentiviruses (LVs) expressing LV/EGFP/ shProSAP2 or LV/EGFP (control). This revealed a dramatic reduction in ProSAP2/Shank3 levels compared with LV/EGFP or uninfected controls (Fig. 1 F). Intriguingly, ProSAP2/Shank3 downregulation had no effect on the abundance of presynaptic (VGLUT1, Synaptophysin, Synapsin, VAMP2, Piccolo, or Munc13), postsyn- 
A
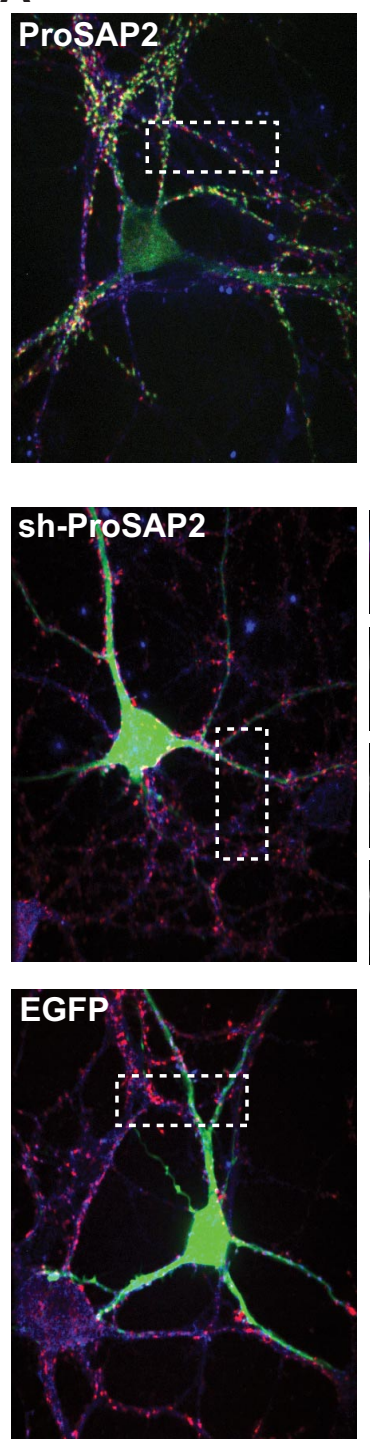
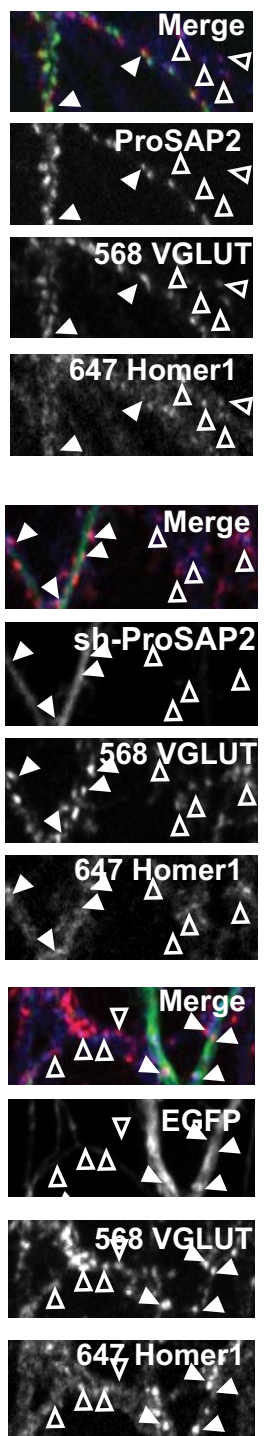

B

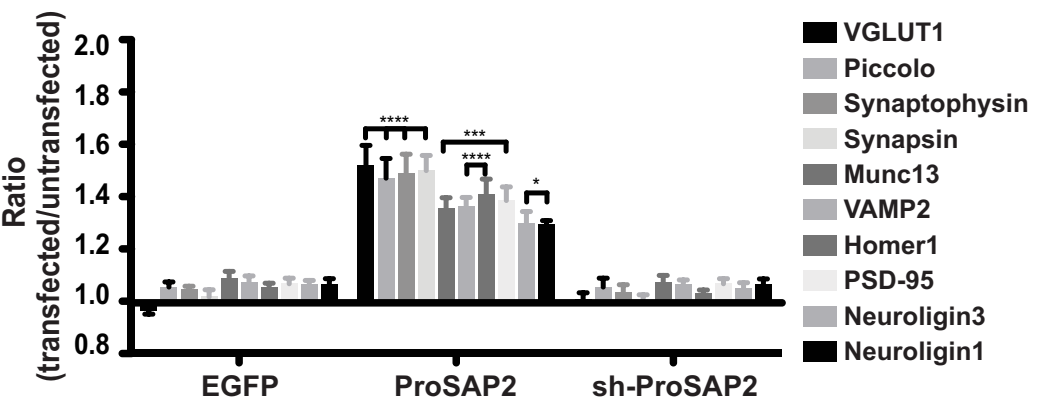

C
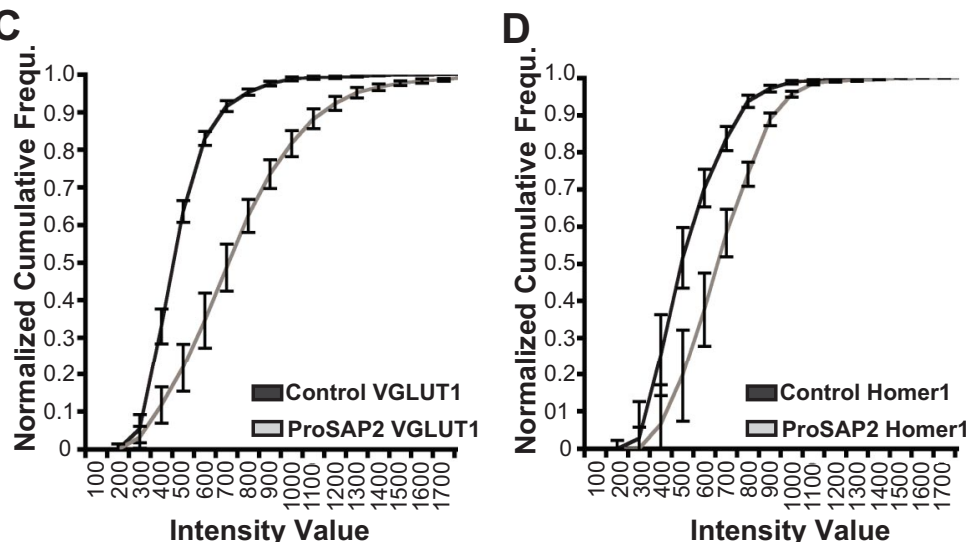

$E$
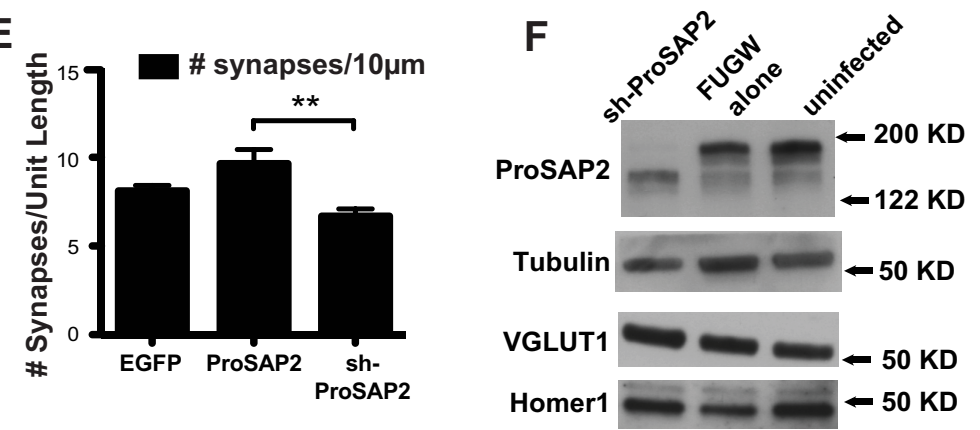

Figure 1. ProSAP2/Shank3 levels mediate transsynaptic changes in synaptic protein content. $A$, Representative images of hippocampal neurons transfected with pEGFP- $\alpha$ ProSAP2 (top), pEGFP/shProSAP2 (middle), or pEGFP (bottom) control on DIV9. Neurons were then fixed at DIV16 and immunostained with antibodies against VGLUT1 (Alexa Fluor 568, shown in red) and Homer1 (Alexa Fluor 647, shown in blue). Filled and open arrowheads mark synapses along dendrites positive or negative for EGFP, respectively. B, Quantification of Alexa Fluor 568 -VGLUT1, Alexa Fluor 647-Piccolo, Alexa Fluor 568 -Synaptophysin, Alexa Fluor 647-Synapsin, Alexa Fluor 568-Munc13, Alexa Fluor 647-VAMP2, Alexa Fluor 647-Homer1, Alexa Fluor 568-PSD-95, Alexa Fluor 568 -NL-1, and Alexa Fluor 568 -NL-3 signal intensity at EGFP-positive versus EGFP-negative points using a puncta-by-puncta analysis strategy. Approximately 150 - 400 puncta were selected and analyzed per image. Ratios of synaptic protein marker values were calculated for EGFP-colocalizing versus non-colocalizing puncta from 7-15 images per condition: presynaptic VGLUT1 (1:55 ratio), Piccolo (1:50 ratio), Synaptophysin (1:51 ratio), Synapsin (1:53 ratio), Munc13 (1:38 ratio), VAMP2 (1:38 ratio), postsynaptic Homer1 (1:43 ratio), PSD-95 (1:41 ratio), NL-1 (1:31 ratio), and NL-3 (1:32 ratio). $\boldsymbol{C}, \boldsymbol{D}$, Cumulative histograms for VGLUT1 and Homer1 illustrate that the puncta intensity values are shifted across the entire populations of EGFP- $\alpha$ ProSAP2 colocalizing versus non-colocalizing puncta. $\boldsymbol{E}$, Number of synapses per unit length. The number of EGFP-containing synapses containing both presynaptic VGLUT1 and postsynaptic Homer1 along $10 \mu \mathrm{m}$ of dendrite. F, Western blot showing ProSAP2/Shank3 expression compared with tubulin, VGLUT1, and Homer1 in neurons uninfected (control) or infected with LVs expressing EGFP or EGFP/shProSAP2. FUGW, Flap-Ub promoter-GFP-WRE. ${ }^{*} p<0.05,{ }^{* *} p<0.01,{ }^{* * *} p<0.001,{ }^{* * * *} p<0.0001$.

aptic (PSD-95, Homer1), or transsynaptic (NL1 and NL3) proteins (Fig. $1 B$ ) or the size of the TRP of SVs (Fig. $2 B, D$ ), but synapse number/length of dendrite was reduced ( 6 synapses/10 $\mu \mathrm{m}$ vs 8 synapses/10 $\mu \mathrm{m}$ ) (Fig. 1 E). These data reveal that ProSAP2/Shank3 is not essential for excitatory synapse formation, consistent with previous reports (Roussignol et al., 2005; Grabrucker et al., 2011a).

ProSAP2/Shank3-induced presynaptic changes are mediated by transsynaptic Neurexin-Neuroligin complex formation Synaptic complexes between Neurexins and Neuroligins are known to promote synapse formation and maturation (Scheiffele et al., 2000; Dean et al., 2003; Graf et al., 2004; Wittenmayer et al.,
2009), as well as enhance presynaptic function (Futai et al., 2007). Because ProSAP2/Shank3 can directly interact with the C-terminal tails of Neuroligins (Meyer et al., 2004) (M.S. and T.M.B., unpublished observations), we investigated whether Nrx/NL complexes mediated ProSAP2/Shank3-induced transsynaptic signaling (Fig. 3). This was accomplished by acutely adding affinity-purified $\operatorname{Nrx} 1 \beta(+\mathrm{S} 4)-\mathrm{Fc}$ to cultures of hippocampal neurons transfected with EGFP $-\alpha$ ProSAP2. This soluble region of the extracellular domain of Nrx was shown previously to block the formation of transsynaptic Nrx/NL complexes (Siddiqui et al., 2010). As a negative control, a soluble neurexin $1 \beta$ lacking its LNS (for Laminin- $\alpha$, Neurexin, and sex hormone-binding glob- 
A

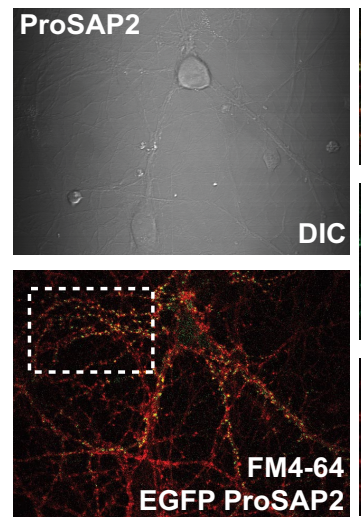

C
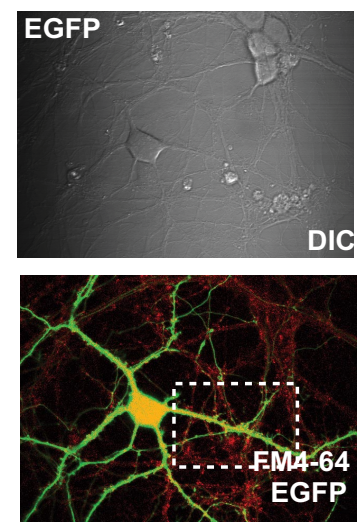

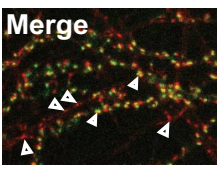

ProSAP2,
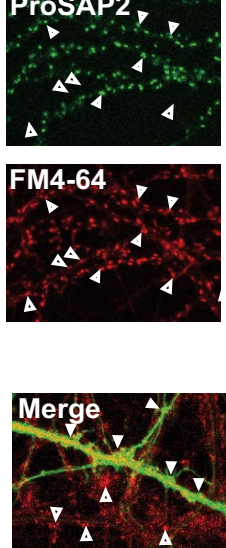

EGFP

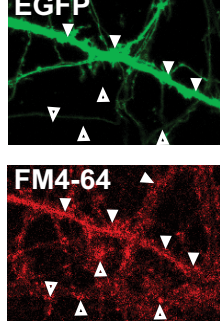

B
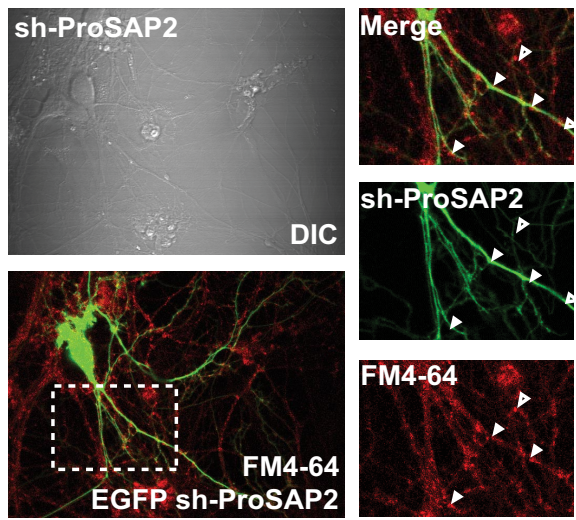

Sh-PIOSAP2
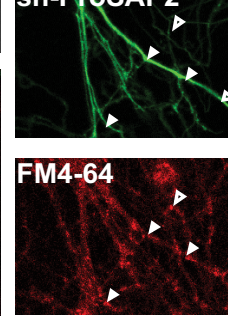

D

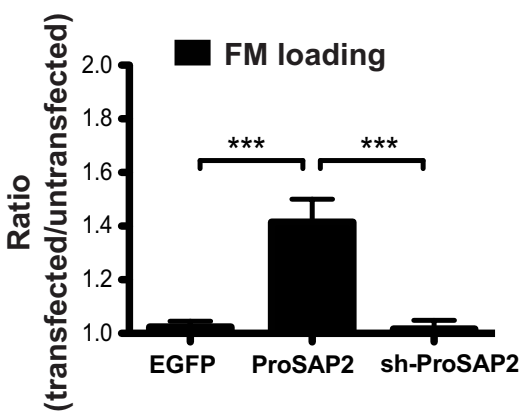

Figure 2. Transsynaptic changes in protein levels are associated with functional changes, as evidenced by FM4-64. A-C, Representative images of neurons transfected with EGFP- $\alpha$ ProSAP2 (A), EGFP/shProSAP2 (B), or EGFP control (C) (green) in which the TRP of SVs was labeled using FM4-64 (red) along with corresponding differential interference contrast (DIC) images. D, Quantification of FM4-64 puncta intensity on neurons transfected with pEGFP- $\alpha$ ProSAP2, pEGFP/shProSAP2, or EGFP control cells. Ratios of FM4-64 puncta intensity were calculated by comparing FM4-64 values at EGFP-colocalizing versus non-colocalizing puncta. A significant increase in FM loading is seen in EGFP- $\alpha$ ProSAP2-expressing cells $\left({ }^{* * *} p<0.001\right)$.

ulin) domain ( $\operatorname{Nrx} 1 \beta-\Delta \mathrm{LNS}-\mathrm{Fc})$ (a domain essential for NL binding) was used (Siddiqui et al., 2010). Experimentally, this was accomplished by adding $50 \mu \mathrm{g} / \mathrm{ml} \operatorname{Nrx1} \beta(+\mathrm{S} 4)-\mathrm{Fc}$ or $\operatorname{Nrx} 1 \beta-\Delta$ LNS-Fc (daily on DIV12-DIV14) to hippocampal neurons transfected with EGFP- $\alpha$ ProSAP2 at DIV12, followed by immunostaining against VGLUT1 and Homer1 on DIV14. The addition of Nrx1 $\beta(+S 4)-F c$ was found to disrupt the EGFP$\alpha$ ProSAP2-induced increase in presynaptic VGLUT1 levels but had no effect on the upregulation of postsynaptic Homer1 (Fig. $3 A, B)$. Addition of the control peptide, $\operatorname{Nrxl} \beta-\Delta \mathrm{LNS}-\mathrm{Fc}$, had no effect on the synaptic levels of either protein (Fig. $3 B$ ).

To explore the specificity of the Neurexin-Neuroligin transsynaptic signaling, we also examined whether blocking other transsynaptic pathways, such as Cadherin signaling with an $\mathrm{N}$-cadherin antibody or Integrin signaling with a GRGDSP peptide (Regalado et al., 2006), impaired transsynaptic signaling induced by the overexpression of EGFP- $\alpha$ ProSAP2. Although the addition of $\operatorname{Nrx} 1 \beta(+S 4)-F c$ completely abolished this transsynaptic signal, addition of the N-cadherin antibody or the GRGDSP peptide only reduced ProSAP2/Shank3-induced presynaptic increases in VGLUT1 by 15 and 40\%, respectively (Fig. 3B). Intriguingly, although the GRGDSP peptide had a general effect on ProSAP2/Shank3-mediated signaling, i.e., reducing the synaptic levels of both VGLUT1 and Homer1, disrupting Nrx/NL complex formation selectively reduced VGLUT1 levels without affecting the ProSAP2/Shank3-mediated recruitment of Homer1 into dendritic spines. To further investigate the consequences of blocking Neurexin-Neuroligin binding, FM4-64 loading was performed on EGFP- $\alpha$ ProSAP2-expressing neurons that were treated with either $\operatorname{Nrx} 1 \beta(+S 4)-F c$ or Nrx1 $\beta-\Delta$ LNS-Fc control peptide (Fig. $3 C$ ). Blocking Neurexin-Neuroligin binding with the $\operatorname{Nrx} 1 \beta(+S 4)-F c$ peptide interfered with the transsynaptic increase in presynaptic vesicle recycling opposite EGFP$\alpha$ ProSAP2-expressing synapses (Fig. $3 D$ ). These data indicate that presynaptic/postsynaptic signaling by ProSAP2/Shank3 can be uncoupled and, moreover, that the transsynaptic signal that influences presynaptic size/function is mediated primarily through a Neurexin-Neuroligin pathway.

Postsynaptic ProSAP2/Shank3 levels modulate synaptic transmission at excitatory synapses

To investigate whether ProSAP2/Shank3 gain or loss of function leads to specific changes in presynaptic and/or postsynaptic function, we recorded evoked EPSCs between pairs of cultured hippocampal pyramidal neurons in which the postsynaptic neuron was transfected with a plasmid expressing EGFP $-\alpha$ ProSAP2 or EGFP/shProSAP2. In neurons expressing EGFP- $\alpha$ ProSAP2, we observed a dramatic increase in the amplitude of evoked AMPAR-mediated EPSCs (Fig. 4) compared with control, untransfected neurons. When NMDAR-mediated currents were isolated by bath application of CNQX, we observed a similar increase in NMDAR-mediated EPSC amplitude in EGFP$\alpha$ ProSAP2-expressing neurons (Fig. 4). Decreasing ProSAP2/ Shank3 expression levels via shRNA-mediated knockdown 
A

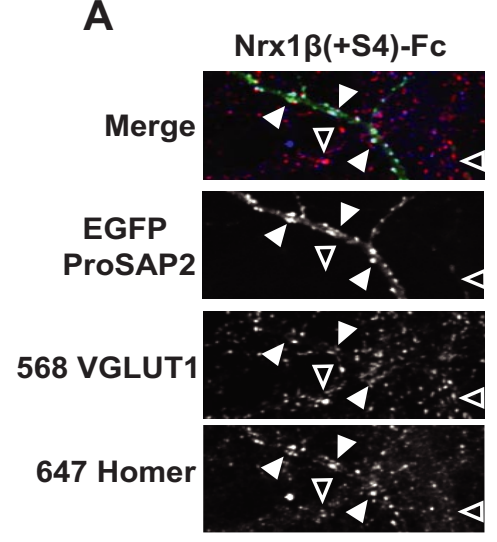

Nrx1 $\beta-\Delta L N S-F c$
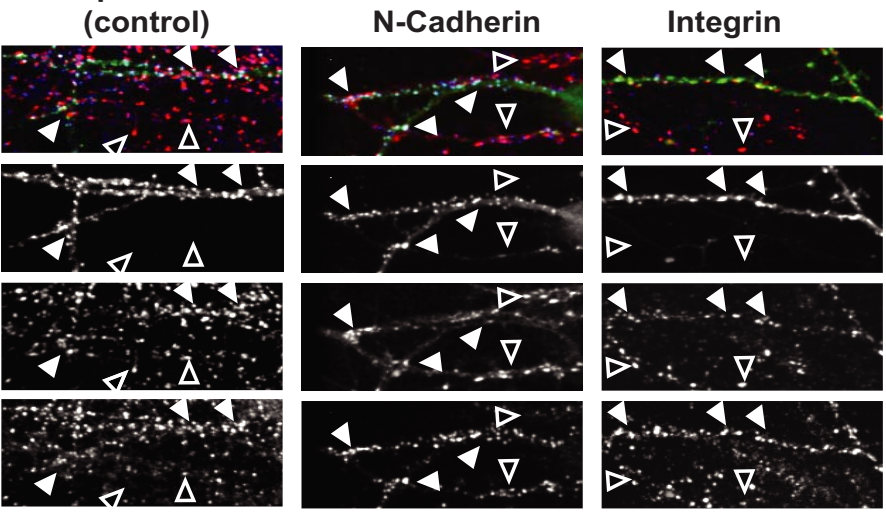

B
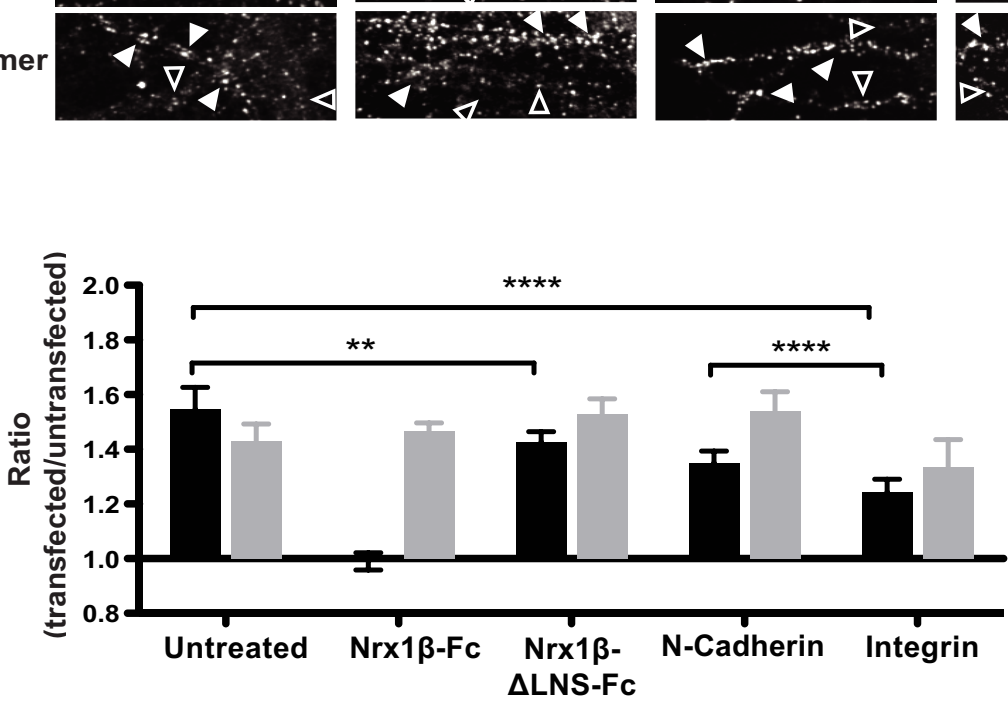

568 VGLUT1

647 Homer1

C

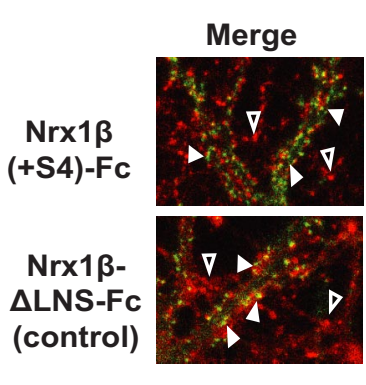

EGFP

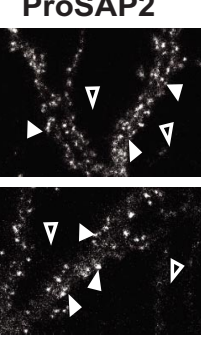

FM4-64

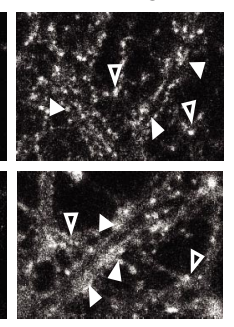

D

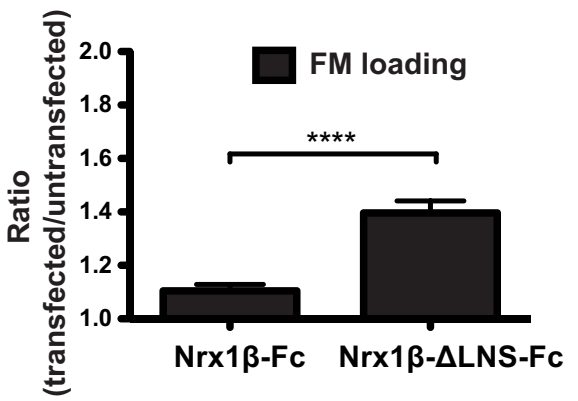

Figure 3. Transsynaptic signaling of ProSAP/Shank proteins depends on Neurexin-Neuroligin binding. Several inhibitors against transsynaptic cell-adhesion molecules (Nrx/Nlg, N-cadherin, Integrin) were applied to cells expressing EGFP- $\alpha$ ProSAP2 (green) and immunostained with antibodies against presynaptic VGLUT1 (red) and postsynaptic Homer1 (blue). $\boldsymbol{A}$, Representative images of EGFP- $\alpha$ ProSAP2-expressing cells treated with soluble Neurexin-1 $\beta(+S 4)-\mathrm{Fc}[\mathrm{Nrx} 1 \beta(+S 4)-\mathrm{Fc}]$, a $\beta$-Nrx control with a mutation in the LNS domain that prevents binding (Nrx1 $\beta-\Delta \mathrm{LNS}-\mathrm{Fc}$ control), N-cadherin antibodies, or a GRGDSP peptide that blocks integrin function. B, Quantification of fluorescent intensities of VGLUT1 and Homer1 at EGFP-colocalizing versus non-colocalizing puncta in cultures treated with GRGDSP, N-cadherin antibodies, or soluble Neurexin-1 $\beta$. Although the integrin blocking peptide had only a minor effect $\left({ }^{* *} p<0.01\right)$, Nrx1 $\beta(+S 4)-\mathrm{Fc} \mathrm{caused} \mathrm{a}$ dramatic reduction in the VGLUT1 $\left({ }^{* * *} p<0.0001\right)$. No significant changes in VGLUT1 were seen in N-cadherin or $\Delta$ LNS control treatment conditions. C, Changes in the TRP of SVs as measured by FM4-64 loading on neurons transfected with pEGFP- $\alpha$ ProSAP2 and treated with the Nrx1 $\beta-\Delta$ LNS-Fc control or Nrx1 $\beta(+S 4)-F c$. Representative images are shown. $D$, Quantification reveals a dramatic block in the size of the TRP of SV in EGFP- $\alpha$ ProSAP2-expressing neurons treated with Nrx1 $\beta(+S 4)-F c$.

(EGFP/shProSAP2), which had no effect on presynaptic protein expression levels or total vesicle recycling pool size (Figs. 1,2), did induce a dramatic decrease in both AMPAR and NMDARmediated EPSC amplitudes to levels well below those of the control, untransfected neurons (Fig. 4). The decrease in synaptic current amplitude likely reflects the observed decrease in synapse number (Fig. 1) and decrease in surface glutamate receptors in neurons lacking ProSAP2/Shank3 (data not shown).

To explore possible transsynaptic effects of ProSAP2/Shank3 on presynaptic function, we initially analyzed failure rates of synaptic transmission. EGFP/shProSAP2 expression significantly in- creased the frequency of failures for AMPAR-mediated currents, whereas EGFP- $\alpha$ ProSAP2 expression decreased failures, although this did not reach significance (Fig. 5). Higher numbers of failures in synaptic transmission can reflect decreased neurotransmitter release probability but can also reflect postsynaptic changes, such as decreases in receptor number (e.g., by an increase in the number of silent synapses). To independently determine whether a change in release probability underlies the observed change in failure rate, we used the NMDAR open channel blocker MK-801. Application of MK-801 blocks NMDARmediated synaptic transmission in a stimulus-dependent man- 


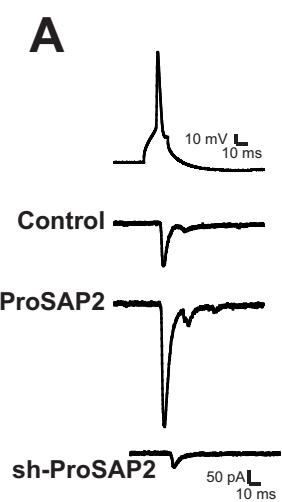

B
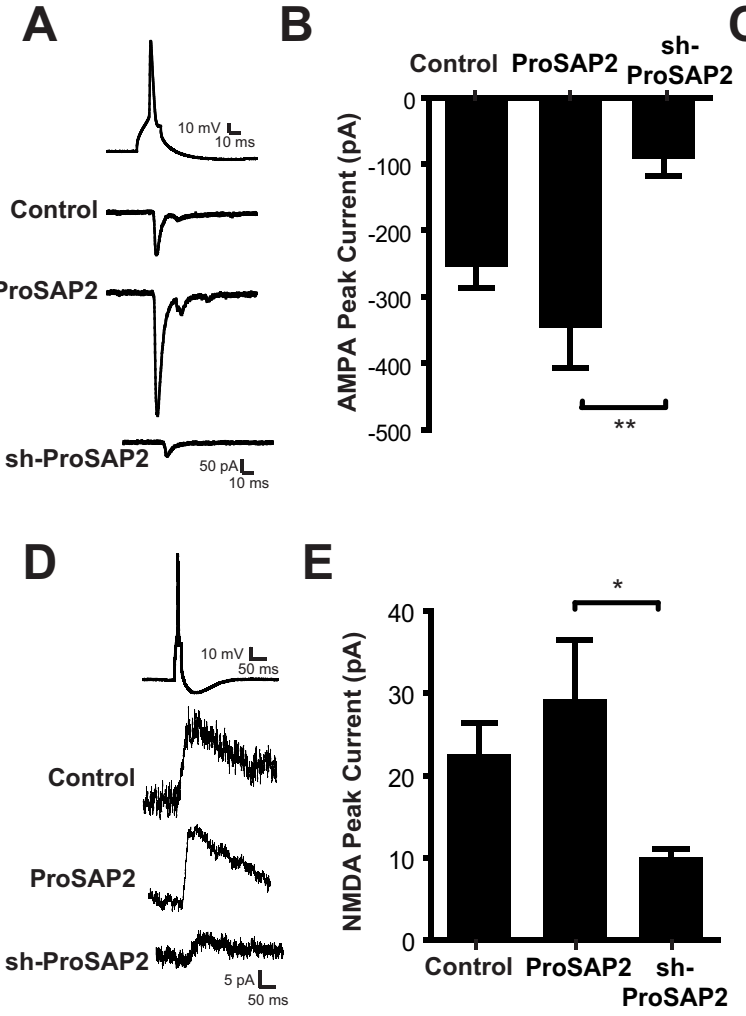

E

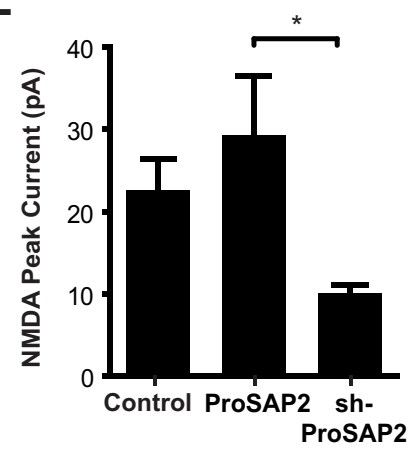

C

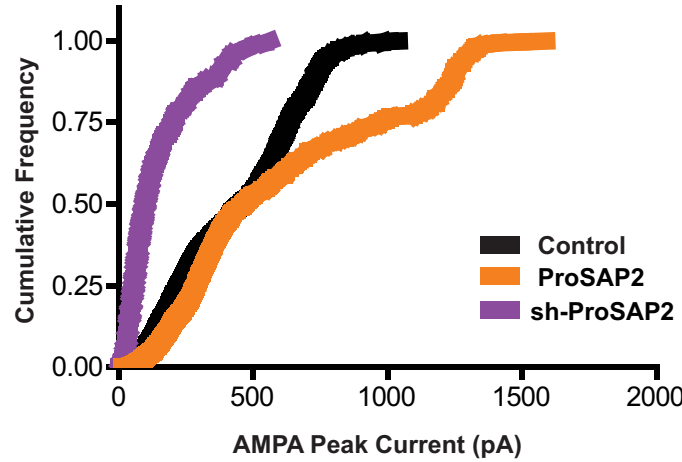

$\mathbf{F}$

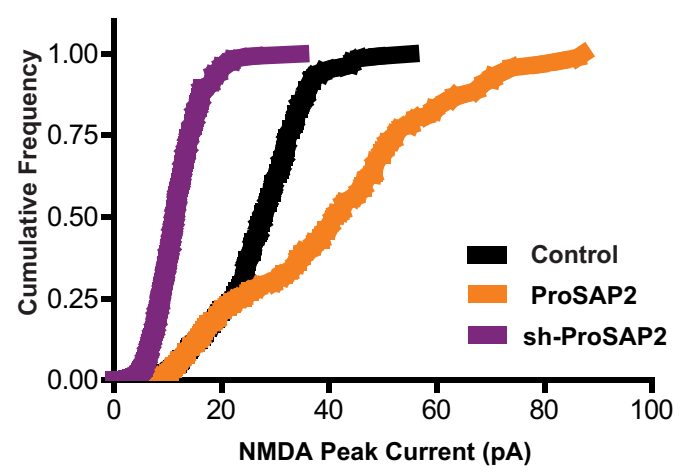

G.

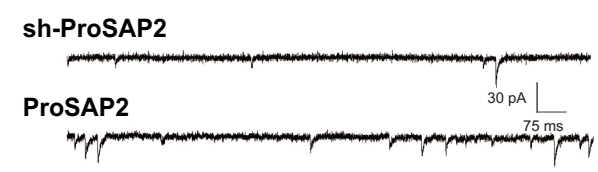

H.

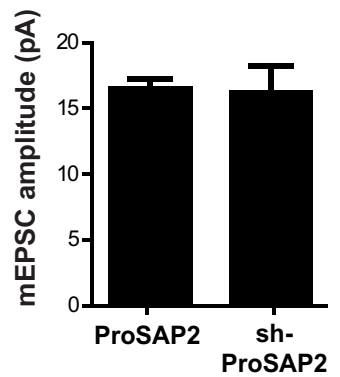

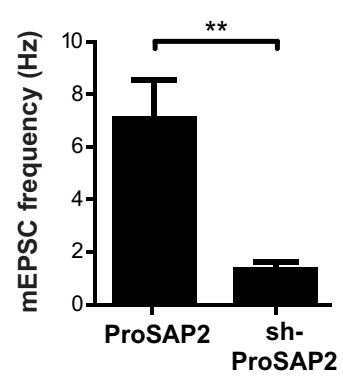

Figure 4. ProSAP2/Shank3 levels alter AMPAR and NMDAR-mediated synaptic transmission. $\boldsymbol{A}$, Example AMPAR-mediated EPSCs from paired recordings between pyramidal neurons in dissociated hippocampal cultures in which the postsynaptic neurons was untransfected (control) or transfected with EGFP- $\alpha$ ProSAP2 (middle) or EGFP/shProSAP2 (bottom). One example action potential is shown (top). $\boldsymbol{B}$, Bar graph of average AMPAR EPSC amplitude in control ( $n=34)$, EGFP- $\alpha$ ProSAP2 $(n=24)$, and EGFP/shProSAP2 ( $n=14)$-expressing neurons. A significant difference between AMPAR EPSC average amplitude in EGFP- $\alpha$ ProSAP2- and EGFP/shProSAP2-expressing neurons was detected by one-way ANOVA $\left({ }^{*} p<0.05\right)$. C, Cumulative probability plot of the same data in $\boldsymbol{B}$. The Mann-Whitney $U$ test determined a significant effect of both EGFP- $\alpha$ ProSAP2 and EGFP/shProSAP2 on AMPAR EPSC amplitudes ( $p<0.001$ in both cases). $\boldsymbol{D}$, Example NMDARmediated EPSCs from paired recordings in which the postsynaptic neurons was untransfected (control) or transfected with EGFP- $\alpha$ ProSAP2 (middle) or EGFP/shProSAP2 (bottom). One example action potential is shown above. $E$, Bar graph of the average NMDAR EPSC amplitude in control $(n=18)$, EGFP- $\alpha$ ProSAP2-expressing $(n=14)$, and EGFP/shProSAP2-expressing $(n=10)$ neurons. One-way ANOVA determined a significant difference $\left({ }^{*} p<0.05\right)$ between EGFP- $\alpha$ PrOSAP2- and EGFP/shProSAP2-expressing neurons. $F$, Cumulative probability plot of NMDAR EPSC amplitudes from $\boldsymbol{E}$. The Mann-Whitney U test determined a significant effect of both EGFP- $\alpha$ ProSAP2 and EGFP/shProSAP2 on NMDAR EPSC amplitudes (*** $p<0.001$ in both cases). G, Example mEPSCs from EGFP/shProSAP2-expressing (top) and EGFP- $\alpha$ ProSAP2-expressing (bottom) neurons. Calibration: $30 \mathrm{pA}, 75 \mathrm{~ms}$. $\boldsymbol{H}$, Average mEPSC amplitudes (left) and frequency (right) in EGFP- $\alpha$ ProSAP2- and EGFP/shProSAP2-expressing neurons, with a significant difference being detected in mEPSC frequency ( ${ }^{* *} p<0.01$ ).

ner: that is, at synapses with a high release probability, MK-801 block of NMDARs occurs faster than at synapses with a low release probability (Rosenmund et al., 1993; Futai et al., 2007). We observed that the rate of NMDAR EPSC block occurred significantly faster between pyramidal cell pairs in which the postsynaptic neuron expressed EGFP- $\alpha$ ProSAP2 compared with pyramidal cells pairs in which the postsynaptic neuron expressed EGFP/shProSAP2 (Fig. 5). The average number of presynaptic action potentials required to decrease the NMDAR EPSC amplitude to $50 \%$ of the original amplitude was $5.9 \pm 1.8$ for EGFP$\alpha$ ProSAP2-expressing neurons versus $26.3 \pm 10.1$ in EGFP/
shProSAP2-expressing neurons (Fig. 5). These data are consistent with an increase in NMDAR channel opening, and consequently increased release probability, in EGFP- $\alpha$ ProSAP2expressing neurons.

To further examine changes in presynaptic function, we recorded the frequency and the amplitude of AMPAR-mediated mEPSCs and the average AMPAR EPSC paired-pulse ratio in EGFP- $\alpha$ ProSAP2and EGFP/shProSAP2-expressing neurons (Fig. 4). We observed that the frequency of mEPSCs in EGFP- $\alpha$ ProSAP2-expressing neurons was significantly higher compared with neurons in which ProSAP2/Shank3 expression was knocked down (average mEPSC 

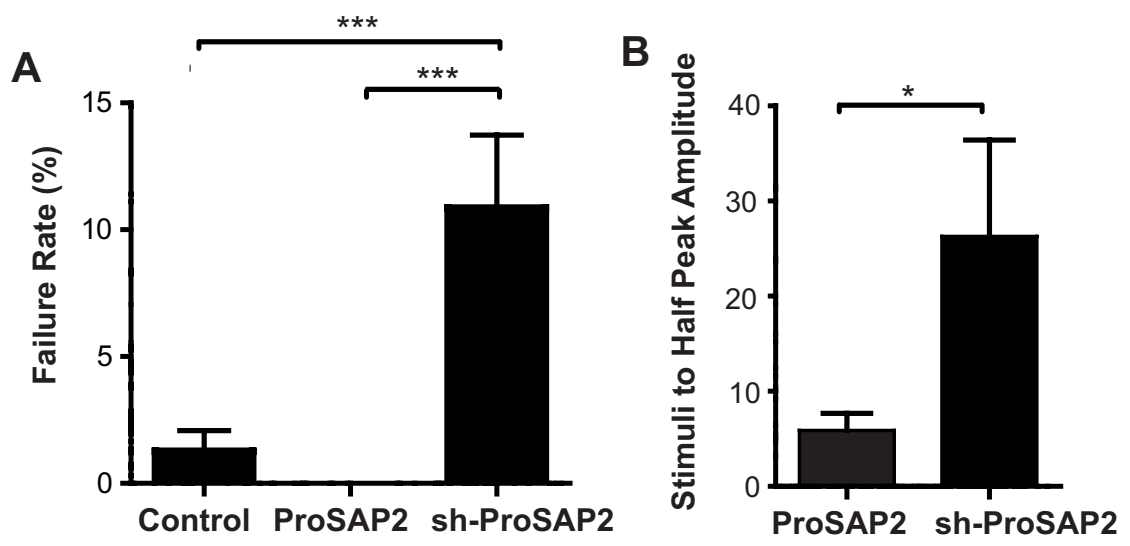

C

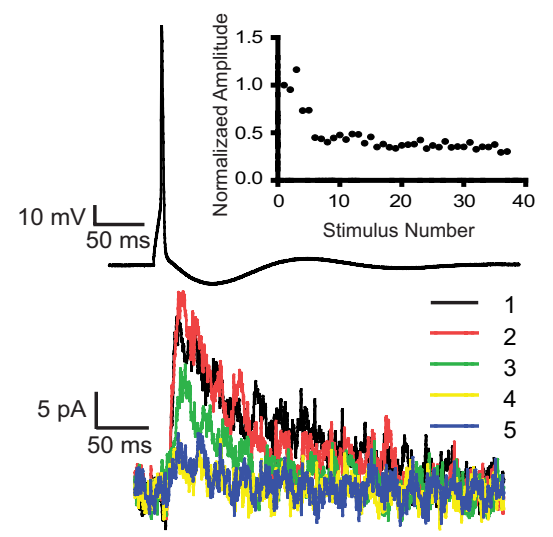

D

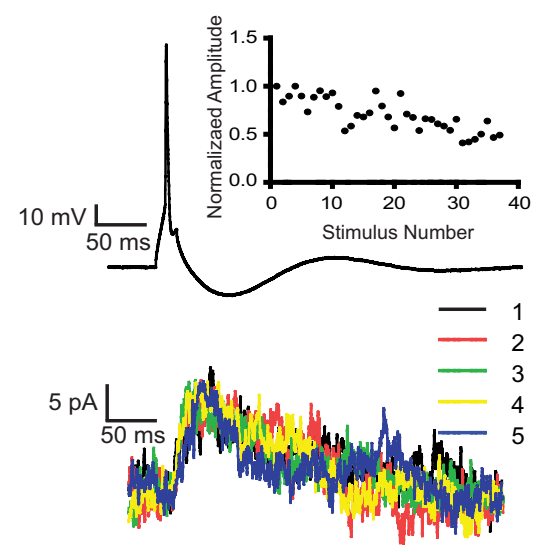

Figure 5. Evidence of presynaptic changes in synapse function with changing postsynaptic ProSAP2/Shank3 levels. $A$, Average failure rates of AMPAR-mediated EPSCs in control $(n=34)$, EGFP- $\alpha$ ProSAP2-expressing $(n=24)$, and EGFP/shProSAP2expressing $(n=14)$ neurons. No failures were detected in pyramidal cell pairs in which the postsynaptic neuron was overexpressing EGFP $-\alpha$ ProSAP2 (*** $p<0.001$ ). $\boldsymbol{B}$, Bar graph of average stimulus number (i.e., presynaptic action potentials) required to decrease the NMDAR amplitude to $50 \%$ of its original amplitude in the presence of MK-801 in EGFP- $\alpha$ ProSAP2-expressing ( $n=$ 6) and EGFP/shProSAP2-expressing ( $n=5$ ) neurons ( ${ }^{*} p<0.05$, determined by two-tailed $t$ test). C, $\boldsymbol{D}$, Example individual experiments for EGFP- $\alpha$ ProSAP2-expressing $(\boldsymbol{C})$ and EGFP/shProSAP2-expressing $(\boldsymbol{D})$ neurons. An example action potential is shown for each recording together with the first five postsynaptic NMDAR-mediated traces after the addition of MK-801. The inset plots show the change in NMDAREPSC amplitude for each example paired recording. Note the rapid decay of the current amplitude in the EGFP- $\alpha$ ProSAP-expressing neuron but the slow decay in the EGFP/shProSAP2-expressing neuron.

frequency was $1.34 \pm 0.27$ and $7.1 \pm 1.45 \mathrm{~Hz}$ in EGFP/ shProSAP2 - and EGFP- $\alpha$ ProSAP2-expressing neurons, respectively; Fig. 4). No significant difference in mEPSC amplitude was evident (16.28 \pm 1.97 and $16.54 \pm 0.67$ pA, respectively; Fig. 4). We also examined the effects of EGFP- $\alpha$ ProSAP2 and EGFP/shProSAP2 on paired-pulse facilitation, which has a presynaptic locus of expression. Synapses with a low probability of release are more prone to exhibiting paired-pulse facilitation, whereas those with a high probability of release favor paired-pulse depression (Katz, 1968; Zucker, 1989; Manabe, 1993). Indeed, we observed that neurons expressing EGFP/shProSAP2 exhibited more paired-pulse facilitation compared with those overexpressing EGFP- $\alpha$ ProSAP2 (the amplitude of the second AMPAR EPSC was on average $1.25 \pm 0.13$ fold higher than the first AMPAR EPSC for EGFP/shProSAP2 compared with $0.96 \pm 0.12$ for EGFP $-\alpha$ ProSAP2; $n=10$ and 9 paired recordings, respectively). Therefore, although ProSAP2/Shank3 is not essential for synapse assembly (Roussignol et al., 2005; Grabrucker et al., 2011a), our data indicate that ProSAP2/Shank3 modulates the functionality and reliability of excitatory synapses, such as neurotransmitter release probability and postsynaptic AMPAR/NMDAR levels.

\section{ASD-associated mutations in ProSAP2/Shank3 interfere with transsynaptic signaling}

Human genetic studies have identified a number of ASD-associated mutations in the ProSAP2/Shank3 gene (Durand et al., 2007; Gauthier et al., 2009; Kumar and Christian, 2009). Three appear as missense mutations in the coding region of ProSAP2/Shank3 (R12C, R300C, Q321R), whereas a fourth (InsG) is a frame-shift mutation, leading to the truncation of the $\mathrm{C}$ terminal of the protein, including (1) the Homer1 binding site (crucial for mGluR signaling), (2) sites for Abp1 and cortactin (involved in F-actin assembly) (Haeckel et al., 2008), and (3) SAM domain (involved in postsynaptic localization) (Grabrucker et al., 2011a). Initial studies of the mutations in cultured neurons indicate some affect on actin assembly and dendritic spine shape and even the frequency of miniature excitatory events (Durand et al., 2012), yet the penetrance of these phenotypes across these mutations is quite variable, suggesting that ProSAP2/Shank3related impairment in synaptic and neural circuit function must be driven by yet illdefined synaptic phenotypes. We were therefore interested in examining whether core deficits in synaptic transmission and transsynaptic signaling, seen in hippocampal neurons lacking ProSAP2/Shank3 (Figs. $1,2,4)$, are shared by neurons expressing these autism-associated mutations in ProSAP2/Shank3. This was accomplished by expressing recombinant EGFP-tagged versions of each mutation in cultured hippocampal neurons. Five facets of ProSAP2/ Shank3 function were then examined, namely, whether the mutations affect (1) synaptic localization of the mutated EGFP$\alpha$ ProSAP2 protein, (2) postsynaptic recruitment of Homer1, (3) transsynaptic increases in VGLUT1 and SV recycling, (4) synapse density, and (5) synaptic transmission. Regarding spatial distribution, we observed a robust postsynaptic localization of EGFP$\alpha$ ProSAP2 carrying each of the corresponding missense mutations (R87C, R375C, and Q396R) in hippocampal neurons transfected at DIV9 and immunostained at DIV14 (Fig. 6). In contrast, EGFP$\alpha$ ProSAP2 carrying the InsG frame-shift mutation exhibited a diffuse somatodendritic pattern consistent with this molecule lacking the synaptic targeting SAM domain (Grabrucker et al., 2011a). Using quantitative immunofluorescent microscopy, all four mutations were found to impair the capacity of ProSAP2/Shank3 to increase postsynaptic levels of Homer1 or presynaptic VGLUT1 levels (Fig. $6 A, B)$. Moreover, compared with wild-type EGFP $-\alpha$ ProSAP2, the size of the TRP of SVs, as measured by FM4-64 loading with $90 \mathrm{~mm}$ $\mathrm{KCl}$, was greatly diminished at presynaptic boutons contacting dendritic profiles of neurons expressing EGFP- $\alpha$ ProSAP 2 carrying each of the autism-associated mutations (Fig. 6C). As in neurons expressing EGFP/shProSAP2, those expressing EGFP- $\alpha$ ProSAP2 ${ }^{\text {InsG }}$ exhibited a similar reduction in synapse density (Fig. 6D). Intriguingly, EGFP $-\alpha$ ProSAP2 carrying the R87C, R375C, and Q396R mutations 
A
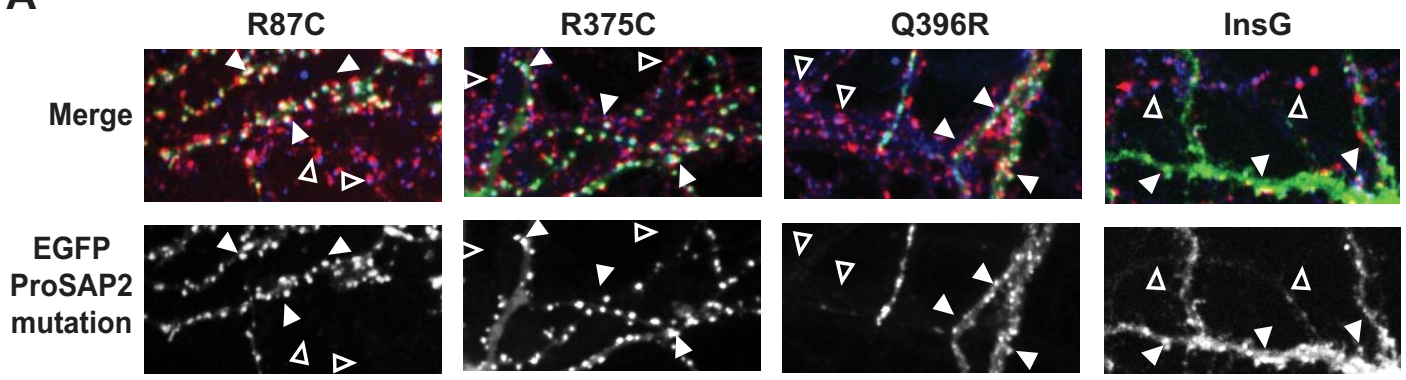

568 VGLUT1
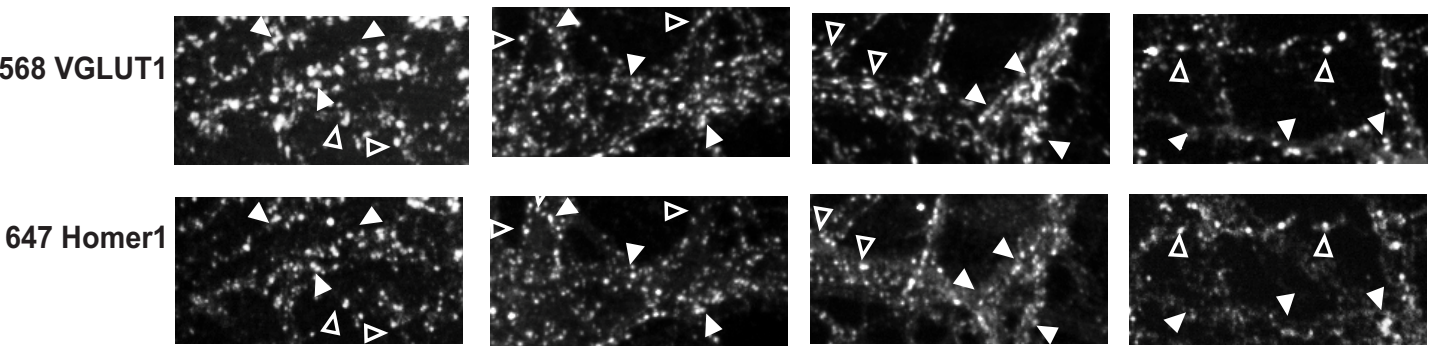

B

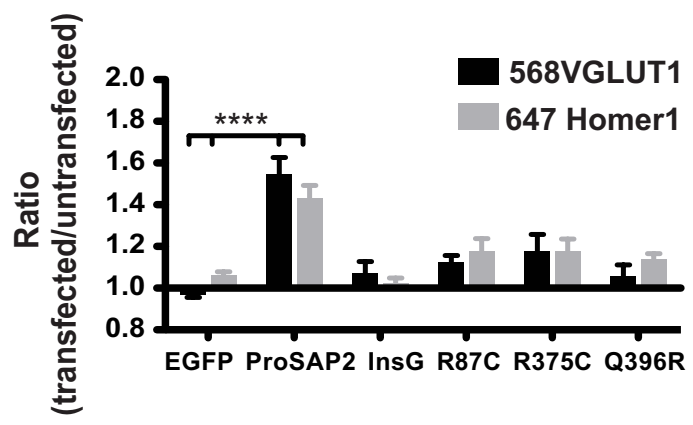

D

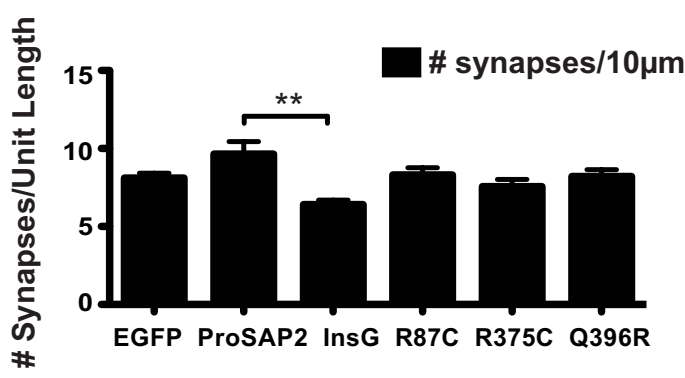

C

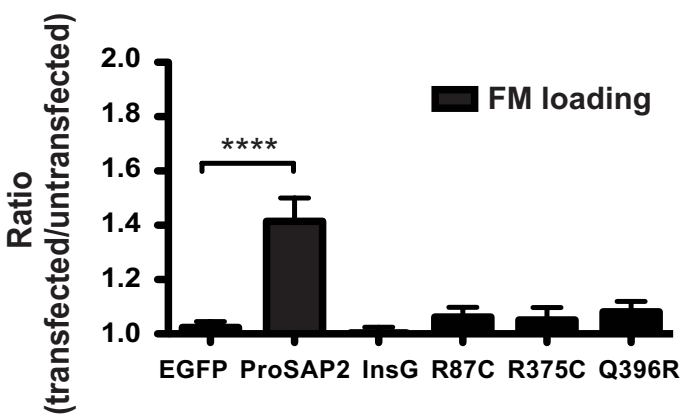

$\mathrm{E}$

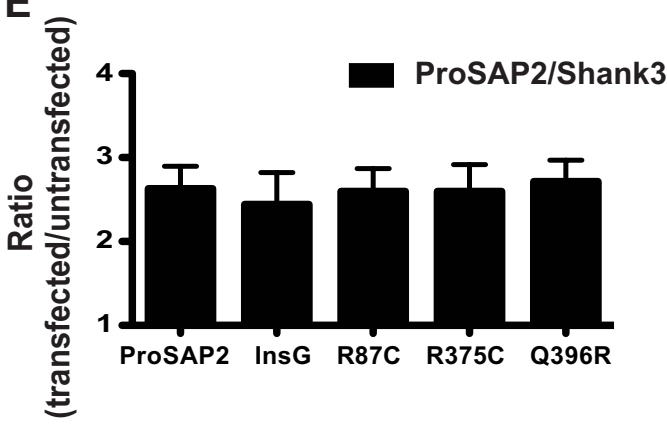

Figure 6. Autism-associated mutations in ProSAP2/Shank3 interfere with transsynaptic signaling. A, Representative images of hippocampal neurons transfected with EGFP- $\alpha$ ProSAP2 carrying autism-associated mutations (R87C, R375C, Q396R, and InsG) at DIV9 and subsequently fixed and stained with antibodies against VGLUT1 and Homer1 at DIV16. Arrowheads label VGLUT1 (red) and Homer1 (blue) colocalizing clusters along dendritic profiles of untransfected (open) or EGFP- $\alpha$ ProSAP2-positive (green) synaptic puncta (filled). $\boldsymbol{B}$, Quantification of puncta fluorescent intensity using a puncta-by-puncta analysis that compares signal intensity values between Alexa Fluor 568 -VGLUT1 and Alexa Fluor 647-Homer1 puncta that colocalize with EGFP-positive sites and Alexa Fluor 568 -VGLUT1 and Alexa Fluor 647-Homer1-only sites (*** $p<0.0001$ ). C, Quantification and comparison of the size of the TRP of SVs measured with FM4-64 in neurons expressing wild-type or autism-associated mutations in EGFP- $\alpha$ ProSAP2 (R87C, R375C, Q396R, and InsG). Ratios of FM4-64 puncta intensity were calculated by comparing FM4-64 values at EGFP-colocalizing versus non-colocalizing puncta $\left({ }^{* * * *} p<0.0001\right)$. D , The number of EGFP-positive synapses expressing both presynaptic VGLUT1 and postsynaptic Homer1 per $10 \mu \mathrm{m}$ of dendrite from neurons transfected with wild-type or autism-associated mutations in EGFP- $\alpha$ ProSAP2 $\left({ }^{* *} p<0.01\right)$. E, Synaptic levels of ProSAP2/Shank3 levels in neurons expressing wild-type EGFP- $\alpha$ ProSAP2 or autism mutations. Synapses in transfected cells were identified by immunostaining neurons with antibodies against VGLUT1 and ProSAP2/Shank3.

had normal excitatory synapse density (Fig. 6). Importantly, the inability of these three missense mutations to enhance synapse density or transsynaptic signaling was not attributable to differences in the synaptic levels of ProSAP2/Shank3 immunoreactivity in transfected neurons (Fig. 6E).

These data indicate that facets of ProSAP2/Shank3 function associated with transsynaptic signaling are similarly impaired by shRNA-mediated knockdown of ProSAP2/Shank3 and by over- expression of autism-associated missense and frame-shift mutations in ProSAP2/Shank3. To explore this relationship further, we performed a more detailed functional analysis of synaptic transmission in neurons transfected with EGFP- $\alpha$ ProSAP2 carrying the R87C, R375C, Q396R, and InsG mutations using paired whole-cell recordings. As in neurons expressing EGFP/shProSAP2, we observed a dramatic decrease in the amplitude of both AMPAR and NMDAR-mediated EPSCs (Fig. 7). This decrease 
A

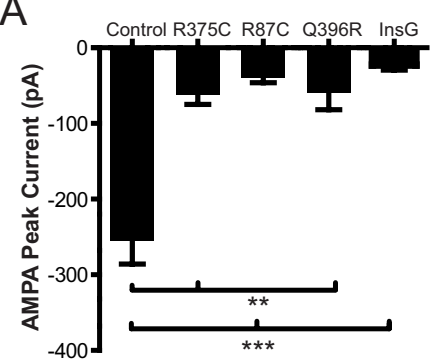

C

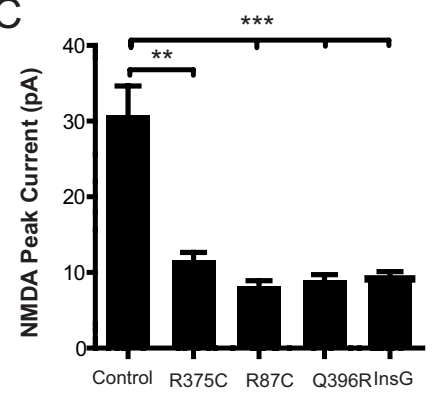

$E$

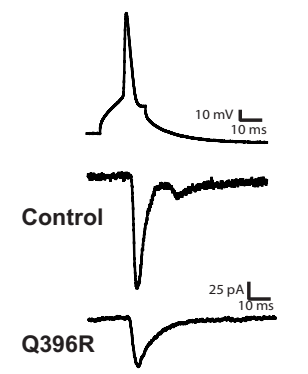

B

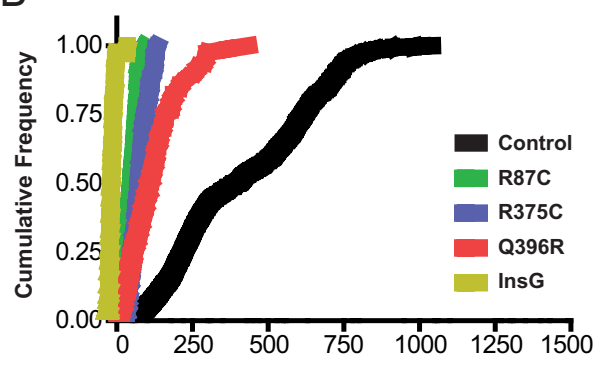

D

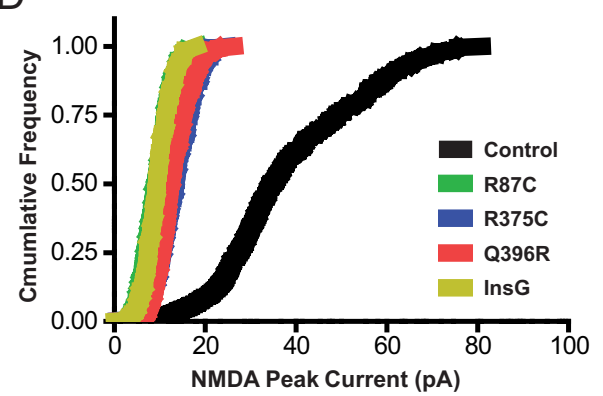

$\mathrm{F}$

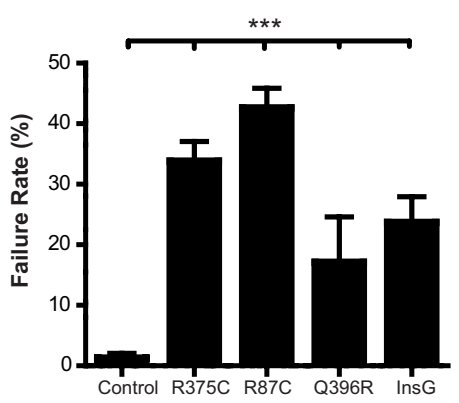

Figure 7. Autism-associated mutations in ProSAP2/Shank3 interfere with AMPAR and NMDAR-mediated synaptic transmission. $\boldsymbol{A}-\boldsymbol{D}$, AMPAR-mediated $(\boldsymbol{A}, \boldsymbol{B})$ and NMDAR-mediated $(\boldsymbol{C}, \boldsymbol{D})$ EPSCs measured from hippocampal pyramidal cell pairs in which the postsynaptic neuron is expressing one of the EGFP- $\alpha$ ProSAP2 autism-associated mutations ( $R 375 C$, R87C, Q396R, or InsG). $A$, Bar graph of average AMPAR EPSC amplitudes in untransfected controls $(n=39), \operatorname{R375C}(n=5), \operatorname{R87C}(n=5), \operatorname{Q396R}(n=6)$, and InsG $(n=7)$. Two-tailed $t$ test revealed that all AMPAR EPSC amplitudes in neurons expressing the autism mutations are significantly different from controls $\left({ }^{* *} p<0.01,{ }^{* * *} p<0.001\right) . B$, Cumulative frequency plot of AMPAR EPSC amplitudes in $\boldsymbol{A}$. The Mann-Whitney $U$ test determined a significant effect of all EGFP- $\alpha$ ProSAP2 autism-associated mutations ( $p<0.001$ in all cases). C, Bar graph of average NMDAR EPSC amplitudes in untransfected controls $(n=11), \operatorname{R375C}(n=5), \operatorname{R87C}(n=5)$, Q396R $(n=6)$, and InsG $(n=5)$. All average NMDAR EPSC amplitudes in neurons expressing the autism mutations are significantly different from controls $\left({ }^{*} p<0.05\right)$. D. Cumulative frequency plot of NMDAR EPSC amplitudes in $\boldsymbol{C}$. The Mann-Whitney $U$ test determined a significant effect of all EGFP- $\alpha$ ProSAP2 autism-associated mutations ( ${ }^{* * *} p<0.001$ in all cases). $\boldsymbol{E}$, Example AMPAR-mediated (left) and NMDAR-mediated (right) EPSCs from control and EGFP- $\alpha$ ProSAP2 Q396R-expressing postsynaptic neurons. F, Average failure rate of AMPAR-mediated EPSCs in control, R375C-expressing, R87C-expressing, Q396R-expressing, and InsG-expressing neurons.

was similar for all ASD-associated ProSAP2/Shank3 mutations. We also observed a dramatic increase in the failure rate of evoked AMPAR-mediated EPSCs in all four mutations (Fig. 7). Combined with the above data revealing that autism-associated mutations in ProSAP2/Shank3 decrease the size of the TRP, our data are consistent with each mutation similarly decreasing the fidelity of synaptic transmission via a transsynaptic mechanism that decreases both presynaptic release probability and postsynaptic receptor expression.

\section{Discussion}

Mutations in multiple neuronal genes have been linked to ASDassociated phenotypes, in part by altering neuronal excitability and/or facets of synaptic transmission (Bourgeron, 2009; Kumar

and Christian, 2009). However, as the number of genes linked to ASDs grows, the scientific community is challenged to conceptualize a framework that both can account for why mutations in so many genes cause ASDs and develop therapies that reach beyond a few monogenic forms of autism (Dölen et al., 2010; Wetmore and Garner, 2010). Possible solutions include the identification of cellular programs for which subsets of ASDassociated genes can be shown to participate.

Here we have sought to define the synaptic program regulated by ProSAP2/Shank3. Although ProSAP2/Shank3 is spatially sequestered within dendritic spines and associates with a range of PSD proteins, we find that it regulates facets of synaptic function beyond F-actin assembly and dendritic spine morphology (Qualmann et al., 2004; Roussignol et al., 2005; Haeckel et al., 2008). Specifically, our data indicate that ProSAP2/ Shank3 performs an integrative function that coordinates the reliability of neurotransmitter release with postsynaptic responsiveness. Intriguingly, we also find that ProSAP2/Shank3 signals to presynaptic boutons through the Neurexin-Neuroligin transsynaptic signaling complex, a finding that potentially links ASD-associated mutations in Nrx1 $\beta$ and NL3 with those in ProSAP2/Shank3. Importantly, four different mutations in ProSAP2/Shank3 were all found to impair pre/post coupling of excitatory synapses, implying that transsynaptic signaling through $\mathrm{Nrx} / \mathrm{NL}$ may be a core synaptic program that is adversely affected in at least a subset of patients with ASD.

Several lines of evidence support this concept. We found that the overexpression of the longest ProSAP2/Shank3 isoform ( $\alpha$ ProSAP2/Shank3) (Peça et al., 2011; Wang et al., 2011) triggers an increase in the number, size, and strength of excitatory synapses formed onto transfected cells, as well as a corresponding increase in the levels of several postsynaptic proteins, including PSD-95, Homer1, NL1, NL3, and GluR1. This is consistent with previous studies showing that the overexpression of $\alpha$ ProSAP2/Shank3 increases the number and size of excitatory spiny synapses as well as a shift toward more mushroom-shaped spines (Roussignol et al., 2005). Together with our observation that $\alpha$ ProSAP2/Shank3 overexpression leads to increased synaptic transmission and thus to stronger, more reliable synapses with higher SV release probability and enhanced AMPAR and NMDAR-mediated currents, these data support a role for $\alpha$ ProSAP2/Shank3 in promoting the maturation of excitatory synapses (Sala et al., 2001; Boeckers et al., 2002; Kreienkamp, 2008).

Surprisingly, an analysis of presynaptic protein levels within boutons juxtaposed to dendritic spines expressing EGFP- 
$\alpha$ ProSAP2 revealed that markers of SVs and active zones were dramatically increased. Our data suggest that functional and structural changes regulated by $\alpha$ ProSAP2/Shank3 within dendritic spines were being conveyed transsynaptically to enhance presynaptic bouton size. Importantly, these presynaptic changes were associated with a corresponding increase in the size of the TRP of SVs, a reduction in the failure rate of evoked synaptic transmission, and an enhancement of SV release probability, all measures that postsynaptic ProSAP2/Shank3 levels can transsynaptically modulate presynaptic function.

Additional support for this integrative pre/post function of ProSAP2/Shank3 was acquired by examining whether ProSAP2/ Shank3 loss of function elicited a corresponding reduction in presynaptic function. Surprisingly, using a well-characterized shRNA against $\alpha$ ProSAP2/Shank3 (Roussignol et al., 2005; Haeckel et al., 2008; Grabrucker et al., 2011a), we failed to detect robust changes in the accumulation of pre/post proteins in neurons lacking ProSAP2/Shank3. This result is supported by recent work in which knockdown of Shank3 by RNA interference did not alter total protein levels of the major synaptic proteins (Verpelli et al., 2011). We did observe a modest nonsignificant change in the number of synapses/unit length of dendrites, indicating that ProSAP2/Shank3 is not essential for synapse assembly, a conclusion supported by previous studies (Roussignol et al., 2005; Haeckel et al., 2008; Grabrucker et al., 2011a; Wang et al., 2011). However, our paired whole-cell recordings revealed a profound reduction in synaptic transmission and reliability, evidenced by decreases in the amplitude of AMPAR and NMDAR-mediated synaptic transmission, as well as a dramatic increase in failure rate and a reduction in SV release probability. These latter data indicate that ProSAP2/Shank3 plays a yet more fundamental role in modulating synaptic transmission, e.g., by coupling presynaptic and postsynaptic function to regulate transmitter release and postsynaptic receptor expression, as evidenced by the decreased surface levels of GluR1 in neurons lacking ProSAP2/Shank3. Because presynaptic proteins levels are not altered at synapses lacking postsynaptic ProSAP2/Shank3, we are drawn to the conclusion that some posttranslational event, perhaps acting on known regulators of neurotransmitter release probability, such as Munc13 or RIM1 $\alpha$ (Rosenmund et al., 2003; Schoch and Gundelfinger, 2006), mechanistically underlie these changes.

An important question raised by these studies is how changes in postsynaptic protein levels are communicated presynaptically and are able to influence the activity of corresponding presynaptic boutons. Changes in presynaptic function triggered by the overexpression of $\beta$ SAP97 use a combination of transsynaptic adhesion/signaling molecules, including Integrins, Cadherins, and Ephrin/EphB but not Neurexin-Neuroligin (Regalado et al., 2006; Gottmann, 2008). In contrast, transsynaptic signals triggered by the overexpression of PSD-95 appear to be mediated primarily via NL1-Nrx signaling (Futai et al., 2007). Similar to PSD-95, ProSAP2/Shank3 directly binds the C-terminal tails of both NL1 and NL3 via its PDZ domain (Meyer et al., 2004) (M.S. and T.M.B., unpublished observations), raising the possibility that transsynaptic signals sent by ProSAP2/Shank 3 to presynaptic boutons are transduced via the regulated formation of $\mathrm{Nrx} / \mathrm{NL}$ complexes. Consistent with this concept, the addition of soluble $\operatorname{Nrx} 1 \beta(+$ S4)-Fc completely abolished EGFP- $\alpha$ ProSAP2-induced increases in VGLUT1 levels. Importantly, postsynaptic Homer1 levels remained elevated in EGFP- $\alpha$ ProSAP2-expressing neurons when neurons were treated with $\operatorname{Nrx} 1 \beta(+S 4)-F c$ but not with Nrx1 $\beta-\Delta$ LNS-Fc. The modest effects of disrupting transsynaptic signaling via Integrin or $\mathrm{N}$-cadherin further support the conclusion that ProSAP2/Shank3 signals transsynaptically primarily via Nrx/NL complex formation.

An important but unresolved question is how modulating Nrx/NL complex formation influences presynaptic function. A decade of work supports such a role (Dean and Dresbach, 2006; Jin and Garner, 2008; Soler-Llavina et al., 2011), yet whether changes in release probability are regulated by changing the composition/activity of voltage-gated calcium channels or SV priming factors (e.g., RIM1 $\alpha$, Munc13, Munc18, complexin, etc.) is unclear. Nonetheless, our demonstration that ProSAP2/Shank3 is functionally coupled to Neurexin-Neuroligins signaling is intriguing on several levels. First, similar to ProSAP2/Shank3, autism-associated mutations have been identified in both Neurexins and Neuroligins (Jamain et al., 2003; Chih et al., 2004; Laumonnier et al., 2004; Chubykin et al., 2005; Etherton et al., 2011), raising the possibility that these three molecules are part of a common synaptic signaling complex. Second, Neurexin-Neuroligin complex formation was originally thought to be essential for nascent synapse formation (Chih et al., 2005), but subsequent data suggested that they are not required for synapse formation but rather for the regulation of synapse maturation and the ratio of excitatory to inhibitory synapses and, moreover, that this regulation is isoform specific (Varoqueaux et al., 2006; Chubykin et al., 2007; Wittenmayer et al., 2009). Haploid insufficiency in NL3 and NL4 is thought to impair information flow between neuronal circuits by disrupting the excitatory/inhibitory balance within these networks (Tabuchi et al., 2007; Südhof, 2008; Gogolla et al., 2009; Zhang et al., 2009; Ey et al., 2011). Similarly, mice lacking ProSAP2/Shank3 elicit behavioral changes consistent with autism, such as reduced vocalization and impaired socialization (Bozdagi et al., 2010; Bangash et al., 2011; Peça et al., 2011; Wang et al., 2011). However, the severity of the deficits, the brain regions affected, and even changes in synaptic transmission are highly variable between these mice, likely as a result of the complexity of the expression of multiple transcripts from the ProSAP2/Shank3 gene (Wang et al., 2011).

In addition to ProSAP2/Shank3 deletions and duplications, single point mutations have been identified in patients with ASDs (Durand et al., 2007, 2012; Bourgeron, 2009), including de novo and inherited missense mutations or single nucleotide insertions (Durand et al., 2007; Moessner et al., 2007). Similar to previous reports, missense point mutations in ProSAP2/Shank3 did not alter synaptic localization, although the frame-shift (InsG) did, presumably because of the loss of the synaptic targeting SAM domain (Durand et al., 2012). In transgenic knock-in mice, Shank $3^{\text {InsG }}$ was found to act as a dominant-negative molecule that leads to an increase in polyubiquitination and the degradation of the endogenous ProSAP2/Shank3 and NR1 subunits of the NMDAR (Bangash et al., 2011). Initial studies of R12C, $\mathrm{R} 300 \mathrm{C}$, and Q321R revealed only modest affects on spine morphology and F-actin assembly, with unequal penetrance (Durand et al., 2012).

Here we reveal that alterations in transsynaptic signaling caused by ProSAP2/Shank3 gain or loss of function were also exhibited by neurons expressing ProSAP2/Shank3 carrying the autism-associated mutations R87C, R375C, Q396R, or InsG. Remarkably, similar to knocking down ProSAP2/Shank3, these mutations equally impaired the ability of excitatory synapses to induce postsynaptic increases in Homerl and transsynaptic increases in VGLUT1 levels and failed to increase the size of the TRP of SVs. Moreover, we found that all mutations dramatically decreased the amplitude of both AMPAR and NMDAR EPSCs and significantly increased synaptic failure rate, similar to cells 
expressing an shRNA against ProSAP2/Shank3. Together, our data suggest three major conclusions: (1) that ProSAP2/Shank3 uses its multidomain structure to not only regulate changes in excitatory postsynaptic function but also to coordinate a retrograde response that modulates the reliability of neurotransmitter release from juxtaposed presynaptic boutons; (2) that ProSAP2/ Shank3 mediates pre/post matching through the Neurexin-Neuroligin signaling complex; and (3) that ASD-associated mutations in ProSAP2/Shank3 primarily interfere with the capacity of excitatory synapses to coordinate pre/post function. It will be of considerable interest to determine whether other ASD-associated mutations also converge in this pathway.

\section{References}

Bailey A, Phillips W, Rutter M (1996) Autism: towards an integration of clinical, genetic, neuropsychological, and neurobiological perspectives. J Child Psychol Psychiatry 37:89-126.

Bangash MA, Park JM, Melnikova T, Wang D, Jeon SK, Lee D, Syeda S, Kim J, Kouser M, Schwartz J, Cui Y, Zhao X, Speed HE, Kee SE, Tu JC, Hu JH, Petralia RS, Linden DJ, Powell CM, Savonenko A, Xiao B, Worley PF (2011) Enhanced polyubiquitination of Shank3 and NMDA receptor in a mouse model of autism. Cell 145:758-772.

Berkel S, Marshall CR, Weiss B, Howe J, Roeth R, Moog U, Endris V, Roberts W, Szatmari P, Pinto D, Bonin M, Riess A, Engels H, Sprengel R, Scherer SW, Rappold GA (2010) Mutations in the SHANK2 synaptic scaffolding gene in autism spectrum disorder and mental retardation. Nat Genet 42:489-491.

Boeckers TM, Bockmann J, Kreutz MR, Gundelfinger ED (2002) ProSAP/ Shank proteins-a family of higher order organizing molecules of the postsynaptic density with an emerging role in human neurological disease. J Neurochem 81:903-910.

Bourgeron T (2009) A synaptic trek to autism. Curr Opin Neurobiol 19: 231-234.

Bozdagi O, Sakurai T, Papapetrou D, Wang X, Dickstein DL, Takahashi N, Kajiwara Y, Yang M, Katz AM, Scattoni ML, Harris MJ, Saxena R, Silverman JL, Crawley JN, Zhou Q, Hof PR, Buxbaum JD (2010) Haploinsufficiency of the autism-associated Shank3 gene leads to deficits in synaptic function, social interaction, and social communication. Mol Autism 1:15.

Brakeman PR, Lanahan AA, O'Brien R, Roche K, Barnes CA, Huganir RL, Worley PF (1997) Homer: a protein that selectively binds metabotropic glutamate receptors. Nature 386:284-288.

Chih B, Afridi SK, Clark L, Scheiffele P (2004) Disorder-associated mutations lead to functional inactivation of neuroligins. Hum Mol Genet 13: 1471-1477.

Chih B, Engelman H, Scheiffele P (2005) Control of excitatory and inhibitory synapse formation by neuroligins. Science 307:1324-1328.

Cho KO, Hunt CA, Kennedy MB (1992) The rat brain postsynaptic density fraction contains a homolog of the Drosophila discs-large tumor suppressor protein. Neuron 9:929-942.

Chubykin AA, Liu X, Comoletti D, Tsigelny I, Taylor P, Südhof TC (2005) Dissection of synapse induction by neuroligins: effect of a neuroligin mutation associated with autism. J Biol Chem 280:22365-22374.

Chubykin AA, Atasoy D, Etherton MR, Brose N, Kavalali ET, Gibson JR, Südhof TC (2007) Activity-dependent validation of excitatory versus inhibitory synapses by neuroligin-1 versus neuroligin-2. Neuron 54:919931.

Dean C, Dresbach T (2006) Neuroligins and neurexins: linking cell adhesion, synapse formation and cognitive function. Trends Neurosci 29:21-29.

Dean C, Scholl FG, Choih J, DeMaria S, Berger J, Isacoff E, Scheiffele P (2003) Neurexin mediates the assembly of presynaptic terminals. Nat Neurosci 6:708-716.

Dölen G, Carpenter RL, Ocain TD, Bear MF (2010) Mechanism-based approaches to treating fragile X. Pharmacol Ther 127:78-93.

Durand CM, Betancur C, Boeckers TM, Bockmann J, Chaste P, Fauchereau F, Nygren G, Rastam M, Gillberg IC, Anckarsäter H, Sponheim E, GoubranBotros H, Delorme R, Chabane N, Mouren-Simeoni MC, de Mas P, Bieth E, Rogé B, Héron D, Burglen L, Gillberg C, Leboyer M, Bourgeron T (2007) Mutations in the gene encoding the synaptic scaffolding protein SHANK3 are associated with autism spectrum disorders. Nat Genet 39: $25-27$.
Durand CM, Perroy J, Loll F, Perrais D, Fagni L, Bourgeron T, Montcouquiol M, Sans N (2012) SHANK3 mutations identified in autism lead to modification of dendritic spine morphology via an actin-dependent mechanism. Mol Psychiatry 17:71-84.

Etherton M, Földy C, Sharma M, Tabuchi K, Liu X, Shamloo M, Malenka RC, Südhof TC (2011) Autism-linked neuroligin-3 R451C mutation differentially alters hippocampal and cortical synaptic function. Proc Natl Acad Sci U S A 108:13764-13769.

Ey E, Leblond CS, Bourgeron T (2011) Behavioral profiles of mouse models for autism spectrum disorders. Autism Res 4:5-16.

Friedman HV, Bresler T, Garner CC, Ziv NE (2000) Assembly of new individual excitatory synapses: time course and temporal order of synaptic molecule recruitment. Neuron 27:57-69.

Futai K, Kim MJ, Hashikawa T, Scheiffele P, Sheng M, Hayashi Y (2007) Retrograde modulation of presynaptic release probability through signaling mediated by PSD-95-neuroligin. Nat Neurosci 10:186-195.

Garner CC, Shen K (2007) Structure and function of vertebrate and invertebrate active zones. In: Structural and functional organization of the synapse (Ehlers M, Hell J, eds). New York: Springer, in press.

Gauthier J, Spiegelman D, Piton A, Lafrenière RG, Laurent S, St-Onge J, Lapointe L, Hamdan FF, Cossette P, Mottron L, Fombonne E, Joober R, Marineau C, Drapeau P, Rouleau GA (2009) Novel de novo SHANK3 mutation in autistic patients. Am J Med Genet B Neuropsychiatr Genet 150B:421-424.

Gogolla N, Leblanc JJ, Quast KB, Südhof TC, Fagiolini M, Hensch TK (2009) Common circuit defect of excitatory-inhibitory balance in mouse models of autism. J Neurodev Disord 1:172-181.

Goslin K, Schreyer DJ, Skene JH, Banker G (1988) Development of neuronal polarity: GAP-43 distinguishes axonal from dendritic growth cones. Nature 336:672-674.

Gottmann K (2008) Transsynaptic modulation of the synaptic vesicle cycle by cell-adhesion molecules. J Neurosci Res 86:223-232.

Grabrucker AM, Knight MJ, Proepper C, Bockmann J, Joubert M, Rowan M, Nienhaus GU, Garner CC, Bowie JU, Kreutz MR, Gundelfinger ED, Boeckers TM (2011a) Concerted action of zinc and ProSAP/Shank in synaptogenesis and synapse maturation. EMBO J 30:569-581.

Grabrucker AM, Schmeisser MJ, Schoen M, Boeckers TM (2011b) Postsynaptic ProSAP/Shank scaffolds in the cross-hair of synaptopathies. Trends Cell Biol 21:594-603.

Graf ER, Zhang X, Jin SX, Linhoff MW, Craig AM (2004) Neurexins induce differentiation of glutamatergic and GABAergic specializations by interaction with neuroligins-1 and -2. Soc Neurosci Abstr 30:386.17.

Haeckel A, Ahuja R, Gundelfinger ED, Qualmann B, Kessels MM (2008) The actin-binding protein Abp1 controls dendritic spine morphology and is important for spine head and synapse formation. J Neurosci 28:1003110044.

Irie M, Hata Y, Takeuchi M, Ichtchenko K, Toyoda A, Hirao K, Takai Y, Rosahl TW, Südhof TC (1997) Binding of neuroligins to PSD-95. Science 277:1511-1515.

Jamain S, Quach H, Betancur C, Råstam M, Colineaux C, Gillberg IC, Soderstrom H, Giros B, Leboyer M, Gillberg C, Bourgeron T; Paris Autism Research International Sibpair Study (2003) Mutations of the X-linked genes encoding neuroligins NLGN3 and NLGN4 are associated with autism. Nat Genet 34:27-29.

Jin Y, Garner CC (2008) Molecular mechanisms of presynaptic differentiation. Annu Rev Cell Dev Biol 24:237-262.

Katz B (1969) The release of neural transmitter substances. Liverpool: Liverpool UP.

Kistner U, Wenzel BM, Veh RW, Cases-Langhoff C, Garner AM, Appeltauer U, Voss B, Gundelfinger ED, Garner CC (1993) SAP90, a rat presynaptic protein related to the product of the Drosophila tumor suppressor gene dlg-A. J Biol Chem 268:4580-4583.

Kreienkamp HJ (2008) Scaffolding proteins at the postsynaptic density: shank as the architectural framework. Handb Exp Pharmacol 365-380.

Kumar RA, Christian SL (2009) Genetics of autism spectrum disorders. Curr Neurol Neurosci Rep 9:188-197.

Laumonnier F, Bonnet-Brilhault F, Gomot M, Blanc R, David A, Moizard MP, Raynaud M, Ronce N, Lemonnier E, Calvas P, Laudier B, Chelly J, Fryns JP, Ropers HH, Hamel BC, Andres C, Barthélémy C, Moraine C, Briault S (2004) X-linked mental retardation and autism are associated with a mutation in the NLGN4 gene, a member of the neuroligin family. Am J Hum Genet 74:552-557. 
Leal-Ortiz S, Waites CL, Terry-Lorenzo R, Zamorano P, Gundelfinger ED, Garner CC (2008) Piccolo modulation of Synapsinla dynamics regulates synaptic vesicle exocytosis. J Cell Biol 181:831-846.

Li D, Specht CG, Waites CL, Butler-Munro C, Leal-Ortiz S, Foote JW, Genoux D, Garner CC, Montgomery JM (2011) SAP97 directs NMDA receptor spine targeting and synaptic plasticity. J Physiol 589:4491-4510.

Manabe T, Wyllie DJ, Perkel DJ, Nicoll RA (1993) Modulation of synaptic transmission and long-term potentiation: effects on paired pulse facilitation and EPSC variance in the CA1 region of the hippocampus. J Neurophysiol 70:1451-1459.

Meyer G, Varoqueaux F, Neeb A, Oschlies M, Brose N (2004) The complexity of PDZ domain-mediated interactions at glutamatergic synapses: a case study on neuroligin. Neuropharmacology 47:724-733.

Miles JH (2011) Autism spectrum disorders-a genetics review. Genet Med 13:278-294.

Moessner R, Marshall CR, Sutcliffe JS, Skaug J, Pinto D, Vincent J, Zwaigenbaum L, Fernandez B, Roberts W, Szatmari P, Scherer SW (2007) Contribution of SHANK3 mutations to autism spectrum disorder. Am J Hum Genet 81:1289-1297.

Peça J, Feliciano C, Ting JT, Wang W, Wells MF, Venkatraman TN, Lascola CD, Fu Z, Feng G (2011) Shank3 mutant mice display autistic-like behaviours and striatal dysfunction. Nature 472:437-442.

Phelan MC (2008) Deletion 22q13.3 syndrome. Orphanet J Rare Dis 3:14.

Polleux F, Lauder JM (2004) Toward a developmental neurobiology of autism. Ment Retard Dev Disabil Res Rev 10:303-317.

Qualmann B, Boeckers TM, Jeromin M, Gundelfinger ED, Kessels MM (2004) Linkage of the actin cytoskeleton to the postsynaptic density via direct interactions of Abp1 with the ProSAP/Shank family. J Neurosci 24:2481-2495.

Regalado MP, Terry-Lorenzo RT, Waites CL, Garner CC, Malenka RC (2006) Transsynaptic signaling by postsynaptic synapse-associated protein 97. J Neurosci 26:2343-2357.

Rosenmund C, Clements JD, Westbrook GL (1993) Nonuniform probability of glutamate release at a hippocampal synapse. Science 262:754-757.

Rosenmund C, Rettig J, Brose N (2003) Molecular mechanisms of active zone function. Curr Opin Neurobiol 13:509-519.

Roussignol G, Ango F, Romorini S, Tu JC, Sala C, Worley PF, Bockaert J, Fagni L (2005) Shank expression is sufficient to induce functional dendritic spine synapses in aspiny neurons. J Neurosci 25:3560-3570.

Sala C, Piëch V, Wilson NR, Passafaro M, Liu G, Sheng M (2001) Regulation of dendritic spine morphology and synaptic function by Shank and Homer. Neuron 31:115-130.

Sato D, Lionel AC, Leblond CS, Prasad A, Pinto D, Walker S, O'Connor I, Russell C, Drmic IE, Hamdan FF, Michaud JL, Endris V, Roeth R, Delorme R, Huguet G, Leboyer M, Rastam M, Gillberg C, Lathrop M, Stavropoulos DJ, Anagnostou E, Weksberg R, Fombonne E, Zwaigenbaum L, Fernandez BA, Roberts W, Rappold GA, Marshall CR, Bourgeron T, Szatmari P, Scherer SW. (2012) SHANK1 deletions in males with autism spectrum disorder. Am J Hum Genet 90:879-887.

Scheiffele P, Fan J, Choih J, Fetter R, Serafini T (2000) Neuroligin expressed in nonneuronal cells triggers presynaptic development in contacting axons. Cell 101:657-669.
Schoch S, Gundelfinger ED (2006) Molecular organization of the presynaptic active zone. Cell Tissue Res 326:379-391.

Siddiqui TJ, Pancaroglu R, Kang Y, Rooyakkers A, Craig AM (2010) LRRTMs and neuroligins bind neurexins with a differential code to cooperate in glutamate synapse development. J Neurosci 30:7495-7506.

Soler-Llavina GJ, Fuccillo MV, Ko J, Südhof TC, Malenka RC (2011) The neurexin ligands, neuroligins and leucine-rich repeat transmembrane proteins, perform convergent and divergent synaptic functions in vivo. Proc Natl Acad Sci U S A 108:16502-16509.

Südhof TC (2008) Neuroligins and neurexins link synaptic function to cognitive disease. Nature 455:903-911.

Tabuchi K, Blundell J, Etherton MR, Hammer RE, Liu X, Powell CM, Südhof TC (2007) A neuroligin-3 mutation implicated in autism increases inhibitory synaptic transmission in mice. Science 318:71-76.

Varoqueaux F, Aramuni G, Rawson RL, Mohrmann R, Missler M, Gottmann K, Zhang W, Südhof TC, Brose N (2006) Neuroligins determine synapse maturation and function. Neuron 51:741-754.

Verpelli C, Dvoretskova E, Vicidomini C, Rossi F, Chiappalone M, Schoen M, Di Stefano B, Mantegazza R, Broccoli V, Böckers TM, Dityatev A, Sala C (2011) Importance of Shank3 protein in regulating metabotropic glutamate receptor 5 (mGluR5) expression and signaling at synapses. J Biol Chem 286:34839-34850.

Waites CL, Specht CG, Härtel K, Genoux D, Leal-Ortiz S, Li D, Drisdel RC, Jeyifous O, Cheyne JE, Haertel K, Green WN, Montgomery JM, Garner CC (2009) Synaptic SAP97 isoforms regulate AMPA receptor dynamics and access to presynaptic glutamate. J Neurosci 29:4332-4345.

Wang X, McCoy PA, Rodriguiz RM, Pan Y, Je HS, Roberts AC, Kim CJ, Berrios J, Colvin JS, Bousquet-Moore D, Lorenzo I, Wu G, Weinberg RJ, Ehlers MD, Philpot BD, Beaudet AL, Wetsel WC, Jiang YH (2011) Synaptic dysfunction and abnormal behaviors in mice lacking major isoforms of Shank3. Hum Mol Genet 20:3093-3108.

Wetmore DZ, Garner CC (2010) Emerging pharmacotherapies for neurodevelopmental disorders. J Dev Behav Pediatr 31:564-581.

Wilson HL, Wong AC, Shaw SR, Tse WY, Stapleton GA, Phelan MC, Hu S, Marshall J, McDermid HE (2003) Molecular characterisation of the $22 \mathrm{q} 13$ deletion syndrome supports the role of haploinsufficiency of SHANK3/PROSAP2 in the major neurological symptoms. J Med Genet 40:575-584.

Wittenmayer N, Körber C, Liu H, Kremer T, Varoqueaux F, Chapman ER, Brose N, Kuner T, Dresbach T (2009) Postsynaptic Neuroligin1 regulates presynaptic maturation. Proc Natl Acad Sci U S A 106:13564-13569.

Xiao B, Tu JC, Worley PF (2000) Homer: a link between neural activity and glutamate receptor function. Curr Opin Neurobiol 10:370-374.

Zhai R, Olias G, Chung WJ, Lester RA, tom Dieck S, Langnaese K, Kreutz MR, Kindler S, Gundelfinger ED, Garner CC (2000) Temporal appearance of the presynaptic cytomatrix protein bassoon during synaptogenesis. Mol Cell Neurosci 15:417-428.

Zhang C, Milunsky JM, Newton S, Ko J, Zhao G, Maher TA, Tager-Flusberg H, Bolliger MF, Carter AS, Boucard AA, Powell CM, Südhof TC (2009) A neuroligin-4 missense mutation associated with autism impairs neuroligin-4 folding and endoplasmic reticulum export. J Neurosci 29:10843-10854.

Zucker RS (1989) Short-term synaptic plasticity. Annu Rev Neurosci 12:13-31. 